\author{
Stanisław Wójtowicz \\ stanwojtow@gmail.com, stanislawwojtowicz.pl
}

\author{
Kamil Rozynek \\ rozynek.kamil@gmail.com
}

\title{
Całkowicie prywatna opieka medyczna - próba zarysu
}

Artykuł nadesłany: 2.12.2019; artykuł zaakceptowany: 25.05.2020

Kody klasyfikacji JEL: H51, I11, I12, I13, I18

Keywords: health care, private health care insurance, health behaviour

\begin{abstract}
Fully private medical care - general overview

In this paper, we explore what the market for medical services and products could look like if the state completely withdrew from the area of medical care. In section 1, we demonstrate that medical services would be purchased mainly through direct payments and medical insurance. We analyse two models of medical insurance: guaranteed renewable insurance and health-status insurance. Other types of insurance that may emerge on the market are also discussed. In section 2, we examine how the privatisation of the health-care system would affect the prices of medical services. We analyse fundamental problems of the state-run health care and discuss how they contribute to smaller supply and higher prices of medical services. We then describe how the introduction of market mechanisms would allow to solve many of these problems. We argue that internalisation of the costs of medical care in a free market order would create strong economic incentives for individuals to take better care of their health, and we contrast this with the state-run health care in which these costs are externalised. In section 3, we explore how medical services could be obtained by individuals without sufficient funds. In section 4 , we discuss how the quality of medical care could be ensured without the help of the state. We argue that competition between service providers would be the main guarantor of quality. We also identify mechanisms that would lead to spontaneous emergence of a system of private medical licencing.
\end{abstract}




\section{Wstęp}

Niniejsze opracowanie przedstawia zarys funkcjonowania całkowicie prywatnej opieki medycznej (CPOM). Tym, co różni niniejszy projekt od podobnych przedsięwzięć (Goodman, Musgrave, 1992; Cannon, Tanner, 2007; Schansberg, 2011; Goodman, 2012; Cochrane, 2015), jest jego radykalny charakter. Nie proponujemy reformy państwowego systemu służby zdrowia. Chcemy zastanowić się, jak mógłby wyglądać rynek usług i produktów medycznych, gdyby państwo całkowicie wycofało się z obszaru opieki medycznej. Problem ten można rozbić na kilka pomniejszych. Jak finansowano by usługi medyczne? Jak działałby prywatny system ubezpieczeń zdrowotnych? Czy ludzi byłoby stać na usługi medyczne? Jak kształtowałyby się ceny? Jak rozwiązano by problem osób nieposiadających odpowiednich środków finansowych? Jak regulowano by jakość usług i produktów medycznych? Pełne opracowanie tematu wymaga więc przedstawienia wielu studiów, które prezentować będą szczegółowe rozwiązania wszystkich tych kwestii. Niniejsza praca ma bardziej ogólny charakter i szkicuje całościowy obraz CPOM. Takie szerokie ujęcie wydaje się nam istotne $\mathrm{z}$ dwóch powodów. Po pierwsze, ponieważ różne elementy CPOM są z sobą na różne sposoby powiązane, konieczna jest bardziej ogólna refleksja, która analizować będzie wielopłaszczyznowe relacje między nimi. CPOM jest czymś więcej niż tylko sumą swych części. Po drugie, przedstawienie całościowego ujęcia stymulować może zainteresowanie rozwiązaniami szczegółowymi. W powszechnym przekonaniu funkcjonowanie CPOM jest — ze względów ekonomicznych, politycznych i moralnych — bądź niemożliwe, bądź niepożądane. W konsekwencji ekonomiści i badacze reprezentujący inne dyscypliny rzadko analizują szczegółowe kwestie związane z prywatną opieką medyczną. Niewiara w możliwość funkcjonowania CPOM zniechęca do badań szczegółowych, a brak badań szczegółowych uzasadnia niewiarę w możliwość funkcjonowania CPOM. Przedstawienie przekonywającej całościowej wizji CPOM może więc skłonić większą grupę badaczy do podjęcia problemów szczegółowych (związanych na przykład z funkcjonowaniem ubezpieczeń medycznych).

W naszym przekonaniu CPOM byłby w stanie zaoferować przynajmniej taki sam poziom opieki co państwowa służba zdrowia. System prywatny w przeciwieństwie do państwowego - nie miałby charakteru redystrybucyjnego, w efekcie czego osoby mniej zamożne mogłyby mieć problemy ze zdobyciem środków na opiekę medyczną. Wierzymy jednak, że istnienie tego problemu zostałoby zrównoważone wyższą efektywnością CPOM, jak też specyficzną strukturą zachęt ekonomicznych, generowaną przez ten system. Argumentując na rzecz efektywności CPOM, odwołujemy się do powszechnie znanych (choć nie przez wszystkich uznawanych) argumentów na rzecz wyższości rozwiązań rynkowych nad rozwiązaniami opartymi na centralnym planowaniu. Niniejszy tekst nie pró- 
buje więc „od zera” dowodzić, że wolny rynek jest bardziej efektywną strukturą niż system oparty na centralnym planowaniu. Pisany jest $\mathrm{z}$ wnętrza paradygmatu wskazującego, że wolny rynek jest najbardziej efektywnym systemem gospodarczym, jeśli tylko nie występują szczególne okoliczności prowadzące do pojawiania się tak zwanej zawodności rynku. W naszym przekonaniu - i wbrew dominującej opinii ${ }^{1}$ - zawodności rynku na obszarze opieki medycznej nie są tak duże, by przeważyć szalę na korzyść rozwiązań etatystycznych (szczególnie jeśli weźmiemy pod uwagę kwestię istnienia zawodności państwa). Opieka medyczna może być z powodzeniem produkowana na wolnym rynku.

Przedstawiona przez nas wizja funkcjonowania CPOM jest częścią większego projektu teoretycznego realizowanego w obszarze teorii libertariańskiej (Huemer, 2019; Nozick, 2010; Rothbard, 1998; Rothbard, 2006): zbadania możliwości funkcjonowania społeczeństwa, w którym wszystkie (lub prawie wszystkie) dobra produkowane są bez udziału państwa. Na potrzeby niniejszej pracy zakładamy, że CPOM pojawiłaby się wraz z innymi libertariańskimi reformami. Państwo wycofałoby się nie tylko z obszaru produkcji i regulacji opieki medycznej, ale również między innymi z obszaru opieki społecznej, edukacji, kontroli jakości produktów czy tworzenia prawa dotyczącego ochrony tak zwanej własności intelektualnej. Systemową ramą, wewnątrz której pojawiłby się CPOM, jest więc tak zwane państwo minimalne (państwo ograniczające się do zapewniania porządku publicznego i nieangażujące się $\mathrm{w}$ żadne funkcje redystrybucyjne i regulacyjne) (Wójtowicz, 2016; Hasnas, 2003; Holcombe, 2004) lub anarchokapitalizm (system bezpaństwowy, w którym produkcją bezpieczeństwa, prawa i rozstrzyganiem sporów zajmowałyby się prywatne firmy) (Wójtowicz, 2017; Friedman, 2014; Osterfeld, 1986). Niemniej jednak CPOM może być również rozpatrywana jako projekt funkcjonujący wewnątrz dominującego obecnie modelu państwa redystrybucyjno-regulacyjnego. W tym ostatnim przypadku ewentualne problemy związane z CPOM mogłyby być doraźnie łatane przez państwo, tak jednakże, by nie naruszyć fundamentalnie wolnorynkowego charakteru projektu — przykładowo osoby nieposiadające środków na wykupienie ubezpieczenia zdrowotnego mogłyby otrzymywać od państwa przeznaczone na ten cel vouchery².

1 Wśród najważniejszych problemów związanych z opieką medyczną, które mogą utrudniać jej produkcję na wolnym rynku, wymienia się przeważnie: (1) nieprzewidywalność wydatków na opiekę medyczną w trakcie życia jednostki, (2) asymetrię informacji w relacji lekarz-pacjent, (3) asymetrię informacji w relacji ubezpieczający się-ubezpieczyciel (problem selekcji negatywnej), (4) problem pokusy nadużycia, (5) problem (nie)racjonalności ubezpieczających się, (6) problem ubezpieczenia się od już istniejących chorób, (7) koszty administracyjne związane z ubezpieczeniami, (8) problemy egalitarno-dystrybucyjne, (9) problemy agencji czy (10) problem jakości usług medycznych (zob. na przykład Arrow, 1963; Stiglitz, 2012).

2 Takie rozwiązanie, w którym rynek generuje efektywność, a system voucherów służy do niwelowania nierówności w dostępie do usług medycznych, proponuje między innymi Pauly (2000; 2019). 


\section{Finansowanie usług medycznych w systemie całkowicie prywatnej opieki medycznej}

W ładzie libertariańskim opieka medyczna produkowana byłaby w głównej mierze przez prywatne, nastawione na zysk firmy. Usługi medyczne nabywano by: (1) w formie bezpośrednich opłat i jako abonament, (2) w formie różnego rodzaju ubezpieczeń medycznych.

\subsection{Opłaty bezpośrednie. Abonament}

Jednorazowe opłaty płacone w zamian za wykonanie określonej usługi są najprostszą i najbardziej efektywną metodą finansowania usług medycznych. Opłaty bezpośrednie mogą być z powodzeniem stosowane w przypadku usług, które są relatywnie tanie i/lub da się oszacować, ilu ich będzie potrzebowała dana jednostka w kolejnych etapach życia, co umożliwia odłożenie odpowiedniej puli pieniędzy. W wyniku opłat bezpośrednich finansowane mogłyby być na przykład:

- wizyty u lekarza rodzinnego i specjalistów,

- leki służące do leczenia niegroźnych chorób (na przykład leki na grypę) $\mathrm{i}$ tanie leki/produkty medyczne stosowane w leczeniu chorób przewlekłych,

- mniej skomplikowane procedury diagnostyczne i procedury diagnostyczne niepowiązane $\mathrm{z}$ diagnozowaniem i monitorowaniem chorób przewlekłych (rutynowe badania krwi, badanie EKG, USG, RTG, rezonans magnetyczny przy urazie ortopedycznym itp.),

— niektóre zabiegi czy operacje, zwłaszcza u pacjentów zdrowych, nieobciążonych chorobami przewlekłymi (na przykład operacja przepukliny czy wyrostka robaczkowego),

— opieka dentystyczna itp.

Wydaje się, że nie jest uzasadnione ekonomicznie, by usługi te sprzedawane były w formie ubezpieczenia (Schansberg, 2014)3. Ubezpieczenia wiążą się z istotnymi kosztami zapośredniczenia (oprócz producenta usług medycznych zarobić musi również ubezpieczyciel) oraz kosztami administracyjnymi (proces określania prawdopodobieństwa wystąpienia zdarzenia, ustalania odpowiedniej wysokości składki ubezpieczeniowej jest kosztowny). Co więcej, w przypadku usług opłacanych bezpośrednio pacjent może przeważnie wybierać z większego wachlarza usług, co wiązałoby się z niższymi kosztami. W interesie konsumenta jest więc, by jak najwięcej usług opłacać bezpośrednio. W tym momencie nie jesteśmy w stanie określić, jakie dokładnie procedury finansowane byłyby uiszczane za pomocą opłat bezpośrednich, możemy jednak spekulować, że ich zakres

3 Zob. również pomocną analogię Reginy Herzlinger, która pokazuje, co stałoby się z cenami i jakością śniadań, gdyby nie były one kupowane z zastosowaniem opłat bezpośrednich, ale w formie „ubezpieczenia śniadaniowego” (Herzlinger, 2004).

Ekonomia - Wroclaw Economic Review 26/1, 2020

(C) for this edition by CNS 
byłby szeroki ${ }^{4}$. Im bogatsze społeczeństwo i im niższe ceny usług medycznych (a jak będziemy argumentować, ceny usług medycznych w ładzie wolnorynkowym by spadły), tym większą ich część opłacano by w ten sposób.

Mniej istotną metodą opłacania usług medycznych byłby abonament medyczny. W przypadku abonamentu konsument płaci dostawcy usług medycznych określoną kwotę pieniędzy (raz na miesiąc czy rok), otrzymując w zamian dany pakiet procedur, które może wykorzystać w opłaconym okresie: obejmowałby on wizyty u lekarza rodzinnego, wizyty u specjalistów, podstawowe badania itp. Abonament, mimo że pozornie przypomina ubezpieczenie, bliższy jest w swym charakterze opłatom bezpośrednim: zamiast płacić oddzielnie za pojedynczą procedurę, płacimy większą kwotę, która uprawnia nas do korzystania (jeśli wystąpi taka potrzeba) $\mathrm{z}$ określonej puli procedur $\mathrm{w}$ danym okresie. Zaletą abonamentu może być możliwość zaoferowania niektórych procedur w niższych cenach (sprzedawca abonamentu będzie miał możliwość skuteczniejszego negocjowania cen z dostawcami usług), zwiększenie finansowej płynności jednostki zdrowia, jak również zniwelowanie u klientów międzyokresowych fluktuacji wydatków związanych z chorowaniem (zamiast płacić więcej w okresie choroby, płacimy płaską stawkę przez cały rok).

\subsection{Podstawowe ubezpieczenie medyczne}

O ile opłaty bezpośrednie oraz abonament są dobrą metodą finansowania relatywnie tanich usług medycznych, o tyle nie nadają się do finansowania leczenia poważniejszych chorób, których koszty leczenia są w wielu przypadkach zbyt duże, by jednostki mogły je pokryć ze swoich oszczędności, ale na szczęście przytrafiają się tylko niektórym. Rozwiązaniem tego problemu jest ubezpieczenie medyczne: jeśli w jakiejś grupie tylko część jednostek zapadnie na chorobę, której leczenie będzie wiązać się z bardzo wysokimi kosztami, dla wszystkich jednostek z tej grupy, które nie chcą ryzykować, że znajdą się w sytuacji bez środków na leczenie, jest racjonalne, by złożyć się do wspólnej puli, z której opłacane będzie leczenie tych spośród składających się, którzy zachorują.

Załóżmy, że ryzyko zapadnięcia na chorobę A w danej grupie w ciągu następnego roku wynosi 1\% (w okresie tym zachoruje na nią średnio 1 na 100 osób). Załóżmy, że by ją wyleczyć, potrzeba usług medycznych za 10000 złotych. By ubezpieczyć się od tej choroby w grupie 100 osób, każda z nich musi zapłacić roczną składkę w wysokości minimum $0,01 \times 10000 \mathrm{zł}=100 \mathrm{zł}$. W rzeczywistości będzie to nieco więcej niż 100 zł, na przykład 105 zł. Dodatkowe 5 zł otrzyma ubezpieczyciel, który musi zorganizować proces ubezpieczenia, zabezpieczyć się

${ }^{4}$ Warto zauważyć, że relacje między różnymi formami finansowania usług medycznych nie byłyby stałe. Rozwój medycyny będzie powodował, że kosztowne terapie, które wcześniej trzeba było finansować za pomocą ubezpieczenia, staną się odpowiednio tanie, by mogły być finansowane opłatami bezpośrednimi. 
przed ryzykiem i zanotować zysk. Tym, co zagwarantuje, że składka będzie maksymalnie niska (wynosić będzie 105, a nie 150 czy 300 zł), jest to, że ubezpieczyciele będą musieli konkurować z sobą o względy klientów. Jednostce nie będzie jednak grozić zachorowanie jedynie na A (z prawdopodobieństwem 1\%), ale także na choroby B, C, D..., Z (z różnymi, odpowiadającymi poszczególnym chorobom prawdopodobieństwami). Całkowita wysokość składki ubezpieczeniowej uzależniana byłaby więc od sumy poszczególnych prawdopodobieństw zachorowania na konkretne choroby w danym okresie ubezpieczeniowym, pomnożonych przez koszty leczenia tych chorób (plus koszty administracyjne i zysk ubezpieczyciela). Ubezpieczenie takie określać będziemy mianem podstawowego ubezpieczenia zdrowotnego (PUZ). W zamian za określoną opłatę ubezpieczyciel zobowiązywałby się pokrywać koszty leczenia wymienionych w umowie chorób, na które pacjent zapadłby w okresie ubezpieczenia ${ }^{5}$. Składka prawdopodobnie obejmowałaby także nieprzewidziane zdarzenia, na przykład wypadki czy nieznane choroby. Należy podkreślić, że w systemie tym osoby, które z jakichś względów (wie$\mathrm{ku}$, znanych predyspozycji genetycznych, niezdrowego stylu życia) mają większe prawdopodobieństwo zachorowania na różnego rodzaju choroby, płaciłyby wyższą składkę niż osoby z niższym prawdopodobieństwem zachorowania.

\subsubsection{Problem już istniejących chorób}

Z funkcjonowaniem systemu opartego na PUZ związana jest jednak podstawowa kwestia: osoby, które zachorowały na poważną chorobę, będą mieć problem z wykupieniem kolejnego ubezpieczenia. Wyobraźmy sobie, że u mężczyzny, który wykupił PUZ, po pół roku trwania umowy wykryto nowotwór. Zgodnie z umową ubezpieczyciel pokryłby koszty leczenia nowotworu, jednak gdy okres ubezpieczeniowy by minął i mężczyzna chciałby wykupić nowe PUZ, proponowana przez ubezpieczyciela wysokość składki bardzo by wzrosła, gdyż zachorowanie na nowotwór radykalnie zwiększa prawdopodobieństwo skorzystania w najbliższym okresie z kosztownych usług medycznych. Problem ten określa się czasem mianem problemu tak zwanych już istniejących chorób (ang. pre-existing conditions): osoby, które w trakcie trwania ubezpieczenia zachorowałyby na poważne choroby (wymienić można tu choćby nowotwory, choroby serca czy cukrzycę), nie będą w stanie wykupić ubezpieczenia na kolejny okres, gdyż wysokość składki poszybuje w górę.

Intuicyjnie nasuwającym się rozwiązaniem tego problemu mogłoby być długoterminowe ubezpieczenie medyczne. Klient podpisywałby umowę, w której ubezpieczyciel zobowiązywałby się pokrywać jego wydatki medyczne przez całe życie, on zaś zobowiązywałby się do płacenia (na przykład raz na rok lub miesiąc) składki, która ustalana byłaby przez podzielanie jego spodziewanych

${ }^{5}$ Długość okresu ubezpieczeniowego wyłoniłaby się samorzutnie. Być może wyłoniłaby się jedna, typowa długość okresu ubezpieczeniowego, być może na rynku dostępne będą różne formy umów na różne okresy. 
wydatków medycznych przez całe życie przez spodziewaną liczbę lat (lub miesięcy) życia. Tym sposobem klient nie musiałby się obawiać poważnej choroby, ponieważ ubezpieczyciel nie mógłby podnieść ustalonej wcześniej składki ubezpieczeniowej. Rozwiązanie to może być jednakże problematyczne, gdyż działająca $w$ tak dalekiej perspektywie firma ubezpieczeniowa miałaby problem zarówno $\mathrm{z}$ określeniem średnich przewidywanych wydatków na leczenie, jak i z ustaleniem z góry przysługujących pacjentom koszyków świadczeń. Na oba te elementy — średnie wydatki na leczenie i możliwe do zaoferowania koszyki usług — wpływa bowiem duża liczba dynamicznie zmieniających się czynników, takich jak: rozwój wiedzy medycznej, rozwój technologii, zmiany w metodach zarządzania i prowadzenia działalności ubezpieczeniowej i wreszcie wszelkiego rodzaju zmiany w prawno-gospodarczo-społecznym środowisku, wewnątrz którego działają strony rynkowej wymiany. Rozwiązaniem tego problemu może być seria krótkoterminowych kontraktów zaprojektowanych w ten sposób, by po zakończeniu jednego kontraktu istniały symetryczne zachęty dla ubezpieczyciela i ubezpieczającego się, by podpisać kolejny kontrakt, niezależnie od tego, co wydarzy się w okresie pomiędzy podpisaniem pierwszego i drugiego kontraktu. Takie rozwiązania przedstawili w 1995 roku Pauly, Kunreuther i Hirth, opisując model ubezpieczenia z gwarancją odnawialności (Pauly, Kunreuther, Hirth, 1995), oraz Cochrane, który zaproponował model ubezpieczenia od zmiany statusu zdrowotnego (Cochrane, 1995).

\subsection{Ubezpieczenie zdrowotne z gwarancją odnawialności}

W przypadku ubezpieczenia zdrowotnego z gwarancją odnawialności (UZGO) opisywana już składka ubezpieczeniowa gwarantująca leczenie w okresie obowiązywania umowy (PUZ) powiększona byłaby o dodatkową opłatę, która gwarantowałaby pacjentowi, że jeśli zachoruje w danym okresie ubezpieczeniowym, będzie mógł wykupić kolejne ubezpieczenie w cenie, jaką zapłacą osoby, które nie zachorowały. Klienci płaciliby więc nie tylko za leczenie chorób, na które mogą zachorować w danym okresie ubezpieczeniowym, ale również nadpłacaliby (ang. front loading) pewną sumę pieniędzy, by zabezpieczyć się przed ryzykiem zawyżenia ich przyszłych składek ubezpieczeniowych w wyniku zachorowania. Nadpłaty wykorzystywane byłyby do pokrycia kosztów długoterminowego (wykraczającego poza okres PUZ) leczenia osób, które zachorowały w danym okresie ubezpieczeniowym. W efekcie, w kolejnym okresie ubezpieczeniowym wszyscy klienci - ci zdrowi, u których prawdopodobieństwo wystąpienia wysokich kosztów leczenia jest niskie, i ci z już występującymi chorobami, u których prawdopodobieństwo wystąpienia wysokich kosztów leczenia jest wysokie - mieliby zachętę ekonomiczną, by przedłużyć ubezpieczenie. Ci, którzy zachorowali, dlatego że ich składka byłaby nadal niska, a ci, którzy nie zachorowali, dlatego że nie musieliby ponosić kosztów leczenia osób, które zachorowały, a które znajdą 
się teraz $\mathrm{z}$ nimi $\mathrm{w}$ jednej grupie ubezpieczeniowej. Koszty te zostały bowiem — dzięki nadpłacaniu — poniesione wcześniej (gdyby firma ubezpieczeniowa gwarantowała odnowienie umowy bez wcześniejszej nadpłaty, osoby, które nie zachorowały, nie przedłużyłyby umowy, nie chcąc być zgrupowane w jednej puli z osobami, które zachorowały) ${ }^{6}$. Tym samym polisy typu UZGO gwarantowałyby, że pacjenci, którzy w trakcie trwania okresu ubezpieczeniowego zachorowaliby na poważne choroby, które radykalnie zawyżałyby przyszłe składki ubezpieczeniowe, nie musieliby się martwić wzrostem składek.

Teoretycznie osoby z już istniejącymi chorobami mają prawo do nieprzedłużenia umowy, w praktyce jednakże nie będą mogły tego zrobić, gdyż tylko firma, w której wykupiły UZGO, gwarantuje im odnawialność polisy ubezpieczeniowej po stawkach, które płacą osoby z grupy niskiego ryzyka. Przenosząc się do innej firmy, osoby takie musiałyby zapłacić składkę, która odpowiadałaby pełnym spodziewanym kosztom leczenia w przyszłości i mogłaby być w przypadku osób chorych astronomicznie wysoka. Niemożność zmiany ubezpieczyciela może stwarzać ryzyko, że firma ubezpieczeniowa będzie źle traktować tych klientów, którzy są „skazani na jej usługi”. To złe traktowanie mogłoby polegać bądź na zawyżaniu składki ubezpieczeniowej, bądź na uchylaniu się przed pełnym finansowaniem leczenia pacjenta. Nie należy się jednak tego obawiać. Gwarantowana odnawialność oznacza, że klient z już występującą chorobą nie zapłaci za kolejne ubezpieczenie więcej niż standardowa stawka oferowana zdrowym klientom. By więc zawyżać składki chorych klientów, firma musiałaby je zawyżać także osobom zdrowym, to zaś spowodowałoby ucieczkę tych ostatnich do innych firm. Jeśli chodzi o kwestię uchylania się przed pełnym finansowaniem leczenia pacjenta — czy szerzej: zaniżania jakości usług — działałby tu podobny mechanizm. Firma, która źle traktowałaby przewlekle chorych, byłaby nie tylko narażona $\mathrm{z}$ ich strony na pozwy o niedopełnienie zasad umowy, lecz odstraszałaby zarówno obecnych klientów niskiego ryzyka, którzy nie decydowaliby się na przedłużenie umowy, jak i nowych klientów.

Należy pamiętać, że gwarancja odnawialności nie oznacza stałej składki przez całe życie. Wysokość składki na UZGO byłaby określana przez średnie oczekiwane wydatki zdrowotne osób, które nie zachorowały, czyli osób z grupy niskiego ryzyka (zauważmy jednak, że wraz ze starzeniem się ryzyko zachorowania w kolejnym okresie ubezpieczeniowym wzrasta), powiększone o prawdopodobieństwo przejścia do grupy wysokiego ryzyka w danym okresie ubezpieczeniowym pomnożone przez wszystkie przyszłe „nadmiarowe” dopłaty w stosunku

${ }^{6}$ Chyba że pojawią się dodatkowe — niezwiązane ze zmianami statusu zdrowotnego — czynniki, jak na przykład pojawienie się na rynku bardziej atrakcyjnych produktów ubezpieczeniowych u konkurencji czy zmiany stopnia awersji do ryzyka, zmiany priorytetów życiowych konsumenta itp. To jednakże skłaniać będzie firmę ubezpieczeniową, by oferowała usługi w odpowiedniej jakości/cenie. 
do składek zdrowotnych płaconych przez zdrowe osoby ${ }^{7}$. Takie coroczne ,aktualizowanie" składki jest konieczne ze względu na to, że ubezpieczyciel musi w odpowiedni sposób połączyć wysokość składki ubezpieczeniowej z odpowiednimi koszykami medycznymi, do których będzie ona obligowała (żadna, nawet najlepsza polisa, nie może zapewnić wszystkich możliwych form terapii w dowolnej ilości). Można więc spodziewać się, że składka ta rosłaby wraz z naturalnym procesem starzenia się osób kupujących ubezpieczenie. Niemniej jednak krzywa wzrostu byłaby łagodna, UZGO zabezpieczałoby bowiem przed nieprzewidywanym wzrostem kosztów polisy ubezpieczeniowej.

Przedstawiony model Pauly'ego, Kunreuthera i Hirtha nie ma charakteru czysto teoretycznej spekulacji. Rynek prywatnych ubezpieczeń w Stanach Zjednoczonych w dużym stopniu wykorzystuje model UZGO. Jak wskazują Kunreuther i Pauly, 80\% ubezpieczeń sprzedawanych w USA zawierało gwarancję odnawialności zanim zaczęło to być wymagane (później wprowadzonym) prawem (Kunreuther, Pauly, 2005) ${ }^{8}$.

\subsection{Ubezpieczenie od zmiany statusu zdrowotnego}

Przedstawiony już model UZGO zakłada, że osoba, której stan zdrowia pogorszył się radykalnie w trakcie trwania okresu ubezpieczeniowego, pozostaje do końca życia (chyba że po jakimś czasie wróci do pełni zdrowia) zależna od jednej agencji ubezpieczeniowej. Cochrane zaproponował alternatywny model, który rozwiązywałby ten problem. W modelu Cochrane'a klient wykupuje dwa niezależne od siebie ubezpieczenia: podstawowe ubezpieczenie zdrowotne (PUZ) oraz ubezpieczenie od zmiany statusu zdrowotnego (UZS). Funkcją UZS jest zabezpieczenie klienta przed ponadstandardowym wzrostem składek medycznych w wyniku zachorowania w trakcie trwania PUZ. Jeśli klient zachorowałby na chorobę, w wyniku której musiałby w kolejnych latach płacić wyższe składki (od tych, które płaciłby, gdyby nie zachorował), ubezpieczyciel szacowałby przyszłe koszty leczenia i wpłacałby na specjalne konto klienta (służące wyłącznie do rozliczeń tego typu) różnicę między przewidywanymi składkami (zwiększonymi w wyniku pojawienia się choroby) a składkami, które klient płaciłby, gdyby nie zachorował. Gdy klient wykupywałby PUZ na kolejny okres ubezpieczeniowy, zgromadzone na koncie środki pozwalałyby mu bez problemu wykupić PUZ, nawet gdyby w wyniku choroby wysokość składki wzrastałaby kilku- czy kilkunastokrotnie. Klient mógłby bądź przedłużyć ubezpieczenie u obecnego ubezpieczyciela, bądź wykupić nowe ubezpieczenie u konkurencyjnej firmy. Jeśli klient przedłużałby

${ }^{7}$ Dla jasności wywodu zakłada się tu najbardziej intuicyjny model, to jest obejmujący dwie grupy ryzyka. To samo rozumowanie można zastosować dla dowolnej liczby grup ryzyka.

${ }^{8}$ Niewielkie odstępstwa od przewidywań modelu tłumaczy się między innymi brakiem płynności finansowej młodych klientów oraz ich mniejszą awersją do ryzyka, co osłabia skłonność do akceptowania wyższych składek zawierających nadwyżkę. Niemniej jednak można spekulować, że w systemie CPOM klienci nie będą mogli pozwolić sobie na taki poziom awersji do ryzyka.

Ekonomia - Wroclaw Economic Review 26/1, 2020

(C) for this edition by CNS 
ubezpieczenie $\mathrm{u}$ pierwotnego ubezpieczyciela, działałoby to jak w przypadku UZGO: musiałby płacić taką samą składkę, jaką płaciłby, gdyby nie zachorował. Jeśli chciałby przejść do innego ubezpieczyciela, obecny ubezpieczyciel rozliczałby się z nim, przelewając mu na konto pieniądze, które klient wykorzystywałby do opłacania wyższej składki na PUZ u nowego ubezpieczyciela. System Cochrane'a (w porównaniu z UZGO) zapewniałby klientom większą elastyczność (zmienić ubezpieczyciela mogliby nie tylko zdrowi, ale i chorzy) i zwiększałby konkurencję między ubezpieczycielami. Osoba, która zachorowałaby, nie byłaby już ciężarem, którego ubezpieczyciel chciałby się pozbyć, ale ze względu na zgromadzone na koncie pieniądze byłaby cennym klientem także dla innych firm ubezpieczeniowych.

Zgodnie z wcześniejszym kontraktem pieniądze na tym koncie mogłyby służyć wyłącznie na potrzeby ubezpieczeń, nie byłoby możliwości wydania ich na bieżące potrzeby. Według Cochrane'a musiałoby tak być z trzech powodów: (1) duże kwoty przelewane na zwykłe konto stwarzałyby zachętę do oszustw na przykład przedstawienia fałszywej diagnozy i ucieczki z dużą kwotą pieniędzy; (2) ludzie, którzy otrzymaliby jednorazowo na konto duże kwoty, mogliby wydać je szybko na coś innego i stracić możliwość wykupienia kolejnego ubezpieczenia, co byłoby sytuacją niekorzystną dla ubezpieczyciela; (3) ubezpieczyciele chcieliby, aby środki na indywidualnym koncie były zabezpieczone na wypadek, gdyby stan zdrowia klienta się poprawił. Gdyby klient odzyskał zdrowie (a tym samym przewidywane koszty leczenia istotnie się zmniejszyły), środki będące dotychczas na indywidualnym koncie ubezpieczeniowym wędrowałyby w odwrotnym kierunku, to jest wróciłyby na konto firmy ubezpieczeniowej. W takiej sytuacji klient nie ma już co prawda środków na koncie, ale może bez większych problemów znaleźć innego ubezpieczyciela, bo ponownie znalazł się w kategorii niskiego ryzyka zdrowotnego'.

W jaki sposób ubezpieczyciel określałby, ile środków zabezpieczyć na koncie klienta? Jednym z rozwiązań tego problemu mogłoby być wprowadzenie tak zwanych kategorii zdrowotnych ${ }^{10}$. Status zdrowotny danej osoby można okre-

${ }^{9}$ Istnienie specjalnych indywidualnych kont ubezpieczeniowych nie jest jedynym sposobem okresowego rozliczania długoterminowych wierzytelności. Alternatywnym rozwiązaniem są zobowiązania kontraktowe, w których ubezpieczyciel X zobowiązuje się do wypłaty przewidywanej kwoty dodatkowych wydatków na składki zdrowotne, na konto nowego ubezpieczyciela, w przypadku gdy klient, który trafił do kategorii wysokiego ryzyka, będzie chciał odejść do innego ubezpieczyciela.

10 Istnienie zobiektywizowanych kategorii statusu zdrowotnego (uwzględniających przeciętne przewidywane wydatki zdrowotne), które byłyby możliwe do określenia przez biegłych sądowych, stanowi niezbędny warunek funkcjonowania modelu Cohrane'a (Handel, Hendel, Whinston, 2017). Wynikałoby to z faktu, że w przypadku konfliktu między konsumentem a ubezpieczycielem trzecia strona musiałaby oceniać, czy ubezpieczyciel przekazał na konto klienta odpowiednią sumę pieniędzy, która będzie w stanie pokryć przyszłą zwyżkę składek ubezpieczeniowych. Oczywiście, zakładamy, że w swoim ogólnym zarysie system regulowałby się rynkowo, na zasadzie samowy-

Ekonomia - Wroclaw Economic Review 26/1, 2020

(C) for this edition by CNS 
ślić, przypisując ją do jednej z (przykładowo) 10 kategorii ${ }^{11}$. Osoba z kategorii pierwszej jest całkowicie zdrowa, nie występuje u niej ponadprzeciętne ryzyko wysokich kosztów medycznych. Osoba z kategorii 5 to osoba, u której z prawdopodobnie pojawią się w najbliższym czasie istotne wydatki na leczenie. Osoba z kategorii 9 to osoba, u której należy przewidywać bardzo duże wydatki w następnych latach. Przypisując daną osobę do określonej kategorii i uwzględniając jej wiek, ubezpieczyciel mógłby dość prosto oszacować, ile pieniędzy należy odłożyć na koncie na jej przyszłe leczenie. UZS byłoby więc ubezpieczeniem od będącego efektem choroby przejścia z niższej kategorii zdrowotnej do wyższej: ubezpieczyciel obiecywałby, że w wypadku takiego przejścia chory nie będzie ponosił kosztów zwiększonej składki na PUZ. Składka na PUZ rosłaby naturalnie $\mathrm{z}$ wiekiem (starsza osoba ma większą szansę, że w ciągu następnego roku czy dwóch zachoruje na poważną chorobę) — przed tym klient nie mógłby się ubezpieczyć. Byłby jednak ubezpieczony przed tym, że w wypadku zapadnięcia na tę chorobę przejdzie z niskiej do wysokiej kategorii zdrowotnej.

\subsection{W jaki sposób zmieniałaby się wysokość składek ubezpieczeniowych w ciągu życia?}

Ponieważ UZGO konceptualnie stanowi połączenie PUZ oraz UZS (różnica polega na tym, że w pierwszym przypadku klient w razie zmiany statusu zdrowotnego otrzymuje kontraktowe zobowiązanie do zapewnienia określonego produktu ubezpieczeniowego, w drugim zaś pewną kwotę pieniędzy), możemy założyć, że łączna wysokość UZGO w pewnym przybliżeniu oddaje łączną wysokość PUZ + UZS, jak i to, że dynamika zmian wysokości składek w obu przypadkach ubezpieczeń będzie podobna. Ponieważ PUZ ubezpiecza od kosztów leczenia chorób, na które możemy zapaść w danym roku ubezpieczeniowym, wysokość składki na PUZ powoli rosłaby wraz z wiekiem. Prawdopodobieństwo, że młoda osoba zachoruje na chorobę wymagającą kosztownego leczenia, jest niewielkie i systematycznie zwiększa się z biegiem lat. Podobnie wyglądałaby sytuacja w przypadku UZS. Na wysokość UZS wpływają dwa czynniki: prawdopodobieństwo przejścia w danym roku do wyższej kategorii zdrowotnej (P) oraz przewidywane zwiększenie kosztów składki ubezpieczeniowej do końca życia w wyniku przejścia do wyższej kategorii zdrowotnej (ZKS). P będzie bardzo niskie w młodości i będzie systematycznie rosło wraz z wiekiem. Równocześnie jeśli młoda osoba zachoruje na poważną chorobę,

muszania kontraktów i reputacji, niemniej jednak musiałaby istnieć możliwość sądowej weryfikacji dotrzymywania umów. Zaletą UZGO jest niekonieczność istnienia zobiektywizowanych kategorii zdrowotnych — wystarczyłoby, żeby sądy w razie podejrzenia naruszenia umowy zbadały, czy ubezpieczyciel zapewnia ubezpieczonemu taki sam standard oraz koszyk świadczeń, jaki oferuje pozostałym klientom z niskich kategorii ryzyka.

11 Podobnie jak w przypadku długości okresu ubezpieczeniowego liczba tych kategorii jest przykładowa. Odpowiednie rozwiązania wytworzyłyby się samorzutnie na rynku.

Ekonomia - Wroclaw Economic Review 26/1, 2020

(C) for this edition by CNS 
będzie na nią średnio chorować (generując koszty) dłużej (bo będzie żyła dłużej) niż osoba starsza. ZKS będzie się więc obniżać wraz z wiekiem. Upraszając nieco, można powiedzieć, że wzrost P będzie równoważył spadek ZKS i na odwrót, wypłaszczając krzywą wzrostu UZS ${ }^{12}$. Sumując dynamikę zmiany składek na PUZ i UZS, można powiedzieć, że całkowita składka ubezpieczeniowa (PUZ + UZS, co będzie w przybliżeniu równe UZGO) będzie stopniowo, ale nie drastycznie, rosnąc wraz z wiekiem ${ }^{13}$. Pozwala to wierzyć, że w systemie CPOM jednostki będą w stanie unieść ciężar finansowy związany z ubezpieczeniem medycznym.

\subsection{Inne typy ubezpieczenia: ubezpieczenie kwotowe i prenatalne}

Na rynku pojawiłyby się z pewnością również inne typy ubezpieczenia. Jednym z nich mogłoby być ubezpieczenie kwotowe, które mogłoby być wykupywane równolegle z PUZ i UZS. Ubezpieczenie to gwarantowałoby, że w przypadku zachorowania na poważną chorobę (na przykład nowotwór) pacjent otrzymywałby określoną kwotę pieniędzy, która pomagałaby mu przejść finansowo trudny okres. Dzięki takiemu ubezpieczeniu można by zasypywać dziury w budżecie jednostki, które byłyby efektem zachorowania, a które nie byłyby pokrywane za pomocą pieniędzy z PUZ.

Innym typem ubezpieczenia medycznego byłoby ubezpieczenie prenatalne. Pozwalałoby ono zagwarantować opiekę medyczną dla nowo narodzonego dziecka,

12 ZKS - czyli suma wszystkich potencjalnych podwyżek stawki ubezpieczeniowej w kolejnych latach do końca życia ponad stawkę dla osoby z kategorii typowego ryzyka - może wydawać się bardzo duży dla osoby w młodym wieku. Należy jednak pamiętać o czynnikach ograniczających tę kwotę. Średni czas utrzymywania się nadzwyczajnie dużych kosztów leczenia to 4 lata, potem wydatki znacznie się obniżają (Eichner, McClellan, Wise, 1998). Wynika to z dwóch czynników: (1) Ludzie, którzy przeszli do kategorii wysokiego ryzyka, zazwyczaj żyją o wiele krócej niż ludzie, którzy znajdują się w kategorii niskiego ryzyka. Zdarzają się przypadki osób, które żyją bardzo długo z jakąś generującą ogromne wydatki zdrowotne chorobą, jednak nie jest to sytuacja statystycznie typowa. Bardzo chore osoby przeważnie nie dożywają starości, co statystycznie zmniejsza czynnik ZKS. (2) Statystycznie leczenie poważnych chorób jest najdroższe w okresie ich rozpoznania i tuż po, a z biegiem czasu tanieje. Dla większości chorób wydatki obniżają się z czasem, czyli choroba wykryta w ciągu ostatnich 5 lat generuje wyższe koszty niż choroba wykryta dawniej niż 5 lat (wyjątkami są tutaj podwyższone wartości lipidów, nadciśnienie i niewydolności serca) (Herring, Pauly, 2006). Kilka powodów może składać się na ten obraz. Wiele chorób w początkowej fazie wymaga bardzo rozległej diagnostyki, długotrwałej hospitalizacji, kosztownego leczenia operacyjnego, by następnie — jeśli choroba została opanowana — być dużo mniejszym nakładem środków kontrolowane. W przypadku niektórych schorzeń po pewnym czasie wyczerpują się możliwości terapeutyczne. Czasem choroba wchodzi w stadium remisji. Wydaje się, że osoba, która w bardzo młodym wieku zachorowała na bardzo poważną chorobę wymagającą bezustannego drogiego leczenia i która równocześnie żyje bardzo długo, jest statystycznym wyjątkiem.

13 Przewidywania te potwierdzają analizy Pauly’ego i Herringa, którzy badali dynamikę zmian składek ubezpieczeniowych w przypadku funkcjonujących w USA ubezpieczeń z gwarantowaną odnawialnością (Herring, Pauly, 2006). 
gdyby urodziło się ono z poważną chorobą lub było trwale upośledzone. Rodzice mogliby wykupywać takie ubezpieczenie w momencie zajścia kobiety w ciążę. Gdyby dziecko rodziło się chore, ubezpieczyciel byłby zobowiązany płacić za jego leczenie lub przelewałby na specjalne konto odpowiednią sumę pieniędzy, którymi rodzice mogliby to leczenie opłacać. To ostatnie rozwiązanie stosowane byłoby w przypadku niepełnosprawności dziecka: rodzice otrzymywaliby na specjalne konto pieniądze, które pozwalałyby im radzić sobie w tej trudnej sytuacji. Pojawia się tu problem polegający na tym, że ubezpieczyciele mogliby żądać wykonania badań genetycznych płodu i następnie odmawiać ubezpieczenia w przypadku płodów obarczonych wadami, co w praktyce zmuszałoby rodziców do dokonania aborcji. Problem ten mógłby być rozwiązany przez wykupywanie ubezpieczenia przed poczęciem dziecka (ubezpieczenie prekoncepcyjne) ${ }^{14}$.

\section{Ceny usług medycznych w ładzie libertariańskim}

W poprzednich paragrafach opisaliśmy, w jaki sposób usługi medyczne mogłyby być finansowane na wolnym rynku. Czy jednak jednostki żyjące w ładzie libertariańskim byłoby na nie stać? Jeden z najważniejszych argumentów przeciwko prywatnej opiece medycznej wyrasta z przekonania, że procedury medyczne są niezwykle drogie, w związku z czym byłyby one niedostępne dla istotnej części społeczeństwa. Wydaje się jednak, że powodem, dla którego usługi medyczne są tak kosztowne, jest to, że obszar opieki medycznej jest kontrolowany przez państwo. Można spekulować, że uwolnienie medycyny spod kontroli państwa spowodowałoby obniżenie cen tych usług do poziomu, w którym byłyby one dostępne także dla mniej zamożnych jednostek ${ }^{15}$.

\subsection{Ogólna przewaga systemu wolnorynkowego nad systemem państwowym}

Podstawowym powodem, dla którego ceny usług medycznych zostały obniżone, byłoby radykalne zwiększenie efektywności działania systemu opieki medycznej w wyniku wprowadzenia mechanizmów rynkowych. W systemie wolnorynko-

14 Ponieważ prawdopodobieństwo pojawienia się różnych chorób u dziecka jest w części zależne od genów rodziców, ubezpieczyciel mógłby proponować rodzicom wykonanie testów genetycznych i różnicować stawkę ubezpieczenia w zależności od prawdopodobieństwa wystąpienia poważnych wrodzonych chorób. W efekcie istniałaby silna presja ekonomiczna, by pary, u których ze względów genetycznych występuje wysokie prawdopodobieństwo spłodzenia dziecka obarczonego dużym ryzykiem zachorowania, unikały macierzyństwa (i decydowały się na przykład na adopcję).

15 Mówimy tu o średnich kosztach opieki medycznej ponoszonych przez przeciętną jednostkę. Ceny pojedynczych procedur czy kuracji określonymi lekami mogą być bardzo wysokie, ale jednostka nie będzie bezpośrednio ponosiła tych kosztów, płacić będzie bowiem jedynie składkę ubezpieczeniową. 
wym osoby niezadowolone $\mathrm{z}$ usług świadczonych przez danego producenta mogą zwrócić się do innego producenta. W efekcie producent, który oferuje dobro o zaniżonej jakości/zawyżonej cenie, musi zwiększyć jakość/obniżyć ceny albo zbankrutuje. I na odwrót - jeśli producent będzie potrafił zaproponować klientom produkty i usługi o lepszej jakości/niższej cenie niż konkurencja (dzięki wprowadzeniu jakiejś - nawet najprostszej — innowacji), będzie mógł przyciągnąć większą liczbę klientów i zanotować wyższe zyski. Na wolnym rynku istnieje więc bezpośrednia relacja między jakością/ceną oferowanego produktu a zyskami danego producenta: im lepszy/tańszy produkt, tym większy zysk producenta.

Zgoła odmiennie wygląda sytuacja w systemie państwowym. Fundamentalny problem z państwową opieką medyczną polega na tym, że jest ona wyłączona spod dyscyplinującego mechanizmu rynkowego. Państwowe instytucje oferujące usługi medyczne nie utrzymują się z wpłat klientów, lecz z pieniędzy pochodzących z budżetu państwa. Jeśli klienci są niezadowoleni ze sposobu działania państwowego producenta opieki medycznej, nie mogą przestać płacić na nią swoich podatków, karząc tym samym nieudolnych zarządzających. W państwowej służbie zdrowia nie istnieje bezpośrednie powiązanie między zyskami zarządzających opieką medyczną a jakością/ceną usług medycznych, dlatego nie istnieją odpowiednie zachęty ekonomiczne, by świadczyć te usługi w wysokiej jakości/ niskich cenach. Wobec braku odpowiednich zachęt możemy przewidywać, że jakość usług będzie niska, a ceny wysokie.

Teoretycznie możemy wyobrazić sobie, że państwo próbuje w jakiś sposób symulować działanie mechanizmu rynkowego: nagradzać lepszych producentów usług i karać gorszych, zapewniając odpowiednie zachęty do działania. Takie rozwiązanie jest jednak problematyczne z dwóch powodów. Po pierwsze, stworzenie nierynkowego systemu kontrolowania producentów usług medycznych jest niezwykle skomplikowane i kosztowne. Na wolnym rynku kontrola jakości odbywa się samorzutnie. Gdy marginalni klienci rezygnują z usług nieefektywnego producenta i przechodzą do producenta efektywnego, wysyłają tym samym do obu producentów sygnał informujący ich, czy działają we właściwy sposób. Producenci muszą natychmiast zareagować: ten, który traci klientów, musi szukać powodów takiego stanu rzeczy (co robię źle, co inni robią lepiej, czy mogę ich naśladować, czy mogę stworzyć jakieś innowacje?), ten, który zyskuje klientów, musi odpowiedzieć na nowy stan rzeczy, rozszerzając odpowiednio swoją działalność. Co więcej, informacje, które do nich docierają, wyrażone są w formie liczbowej (odpowiednie mniejsze i większe wpływy) — co umożliwia zarówno określenie skali problemu, przed którym stoją, jak i oszacowanie odpowiednich środków, które są konieczne, by go rozwiązać. By próbować zapewnić poziom kontroli jakości podobny do rynkowego, państwo (wobec braku mechanizmu zysków i strat) musi stworzyć skomplikowany aparat biurokratyczny, które oceniać będzie działania konkretnych producentów. Aparat ten będzie nie tylko niezwykle kosztowny, ale również działać będzie nieefektywnie — informacja nie będzie przekazywana za 
pomocą superczułego, operującego wymiernymi jednostkami systemu cen, ale za pomocą ocen, raportów, standardów, rozporządzeń, regulaminów itd., które tworzone będą na podstawie zagregowanych danych wpływających do centralnego systemu. Wszystkie te dane posłużą biurokratom do tworzenia zasad mających na celu wymuszanie odpowiedniej jakości usług. Pojawia się tutaj jednak wiele problemów (Downs, 1964):

(1) zasady te będą miały charakter ogólny i homogenizujący, co uniemożliwi lokalnym producentom korzystanie z rozproszonej wiedzy („,mógłbym to zrobić lepiej/taniej, ale nie zezwala na to system, który tworzy zasady dla wszystkich");

(2) proces przekazywania informacji będzie bardzo powolny: nim nowe rozwiązania zostaną zaakceptowane i rozpowszechnione, będą musiały być zatwierdzone przez zarządzające systemem centralne instytucje;

(3) proces przekazywania informacji będzie nieefektywny — ponieważ informacja będzie musiała przejść od urzędnika niższego szczebla do urzędników na wyższych szczeblach i z powrotem, zanotujemy bardzo duże „straty informacyjne";

(4) przepływ informacji będzie miał charakter — przynajmniej częściowo opisowy, co utrudni kalkulację ekonomiczną;

(5) przekazujący informacje urzędnicy zarządzający na konkretnych poziomach nie będą mieli odpowiednich zachęt ekonomicznych, by przedstawiać prawdziwe informacje (każda instytucja będzie przedstawiała się w jak najlepszym świetle i wyolbrzymiała problemy, z którymi się spotyka);

(6) lokalnym innowatorom brakować będzie zachęt, by proponować nowe, lepsze rozwiązania, gdyż nie będą mogli zanotować pełnego zysku związanego $\mathrm{z}$ innowacją, który osiągnęliby na wolnym rynku ${ }^{16}$;

(7) centralny zarządca będzie o wiele bardziej konserwatywny w dopuszczaniu innowacji (gdyż konsekwencje nieudanych innowacji będą rozlewały się na całość systemu).

Drugi, być może istotniejszy, problem polega na tym, że rządzący nie mają odpowiedniej zachęty ekonomicznej, by stworzyć efektywny system kontroli jakości usług medycznych. Na wolnym rynku producentów kontrolują klienci robią to, ponieważ kontrola ta jest w ich najlepszym interesie. Gdy konsument wybiera najlepszego i najtańszego producenta danego dobra, dokłada swoją cegiełkę do społecznego systemu kontroli efektywności opieki medycznej, robi to jednakże nie dlatego, że chce rozwiązać istotny problem społeczny, ale dlatego że chce zapewnić sobie jak najlepszą opiekę medyczną w jak najlepszej cenie. Jed-

16 Nawet jeśli w systemie tym wypłacano by „premie za innowacje”, premie te byłyby ustalane w sposób arbitralny przez urzędników państwowych, którzy przyznając je, nie ryzykowaliby własnymi pieniędzmi. Premie takie byłyby jedynie „zabawą w wolny rynek”, do sprawnego funkcjonowania rynku konieczne jest bowiem, by osoba wprowadzająca innowacje: (1) ryzykowała własnymi pieniędzmi (zachęta do bycia ostrożnym) i (2) miała szansę, jeśli innowacja okaże się trafiona, zgarnąć cały zysk związany z jej wprowadzeniem (zachęta do ryzykowania). 
nak w systemie państwowym producentów opieki medycznej kontrolować musi państwo. Kto jednak kontrolować będzie państwo, by dobrze wywiązywało się ze swej roli kontrolowania producentów opieki medycznej? Jest to jeden z najważniejszych problemów filozofii politycznej: jeśli państwo powołane jest do tego, by kontrolować społeczeństwo (zmuszać je do robienia czegoś, czego ono nie chce robić), w jaki sposób społeczeństwo może kontrolować państwo (zmuszać jego do tego, by robiło ono to, czego społeczeństwo od niego chce)? Teoretycznie w systemie demokratycznym istnieje możliwość kontroli jakości opieki zdrowotnej przez społeczeństwo. Jeśli jakość służby zdrowia dramatycznie się pogorszy, wyborcy mogą odwołać aktualnie rządzącą partię - stwarza to pewną zachętę, by rządzący pilnowali producentów opieki medycznej, by te nie doprowadziły do dramatycznego spadku jakości/zawyżania cen usług medycznych. Taki sposób wywierania nacisku na zarządzających służbą zdrowia jest jednak bardzo mało efektywny:

(1) ocenie są poddawane nie poszczególne jednostki oferujące usługi medyczne, ale cały system służby zdrowia;

(2) system jest zbyt skomplikowany, by jednostka mogła ocenić sposób jego działania/efektywność;

(3) oceniający nie mają z czym porównać jego jakości oraz kosztów;

(4) ocena zadowolenia wyborców z jakości opieki medycznej odbywa się (w systemie polskim) raz na 4 lata $\mathrm{w}$ trakcie wyborów i jest połączona $\mathrm{z}$ ocenami innych aspektów działania rządu/państwa (nie wybieramy zarządców służby zdrowia, lecz osoby zarządzające całym państwem);

(5) ponieważ nie ma żadnej gwarancji, że kolejna władza wprowadzi lepszy system opieki zdrowotnej, jego niska jakość/wysoka cena mogą nie stanowić wystarczającej zachęty, by zmienić władzę.

Wszystko to każe wierzyć, że państwo nie jest w stanie efektywnie kontrolować producentów opieki medycznej, by ci świadczyli usługi w wysokiej jakości i niskiej cenie.

Różnice w efektywności opieki medycznej produkowanej państwowo i prywatnie można wyjaśnić w jeszcze inny sposób. W przypadku prywatnej opieki medycznej nikt nie ustala odgórnie, w jaki sposób powinny funkcjonować instytucje ją produkujące. Każda z firm produkuje oferowaną przez siebie usługę na swój sposób. Różne firmy/instytucje będą więc oferowały różne wersje produktu (pluralizacja). Te same problemy, które napotykają producenci opieki medycznej, będą rozwiązywane na różne sposoby przez setki czy tysiące różnych podmiotów z wykorzystaniem lokalnej wiedzy dostępnej dla konkretnych producentów. Produkty te będą następnie oceniane przez klientów wybierających te, które w ich przekonaniu dają najlepsze rezultaty (ewaluacja). Stosujący nieefektywne strategie notować będą straty, w związku z czym zmuszeni będą kopiować tych, którzy znaleźli lepsze metody (emulacja). W efekcie ogólny poziom efektywności służby zdrowia będzie się podnosił. Jednak po wyrówna- 
niu się poziomu jedyną metodą osiągnięcia zysków będzie stworzenie nowych, lepszych produktów (innowacja). Proces ten będzie miał więc ciągły charakter, prowadząc do bezustannego zwiększania się jakości i obniżania ceny usług. Zamiast jednego, centralnego zarządcy, który odgórnie ustala zasady produkowania danego dobra, na rynku funkcjonują tysiące producentów. Producenci ci z jednej strony wykorzystują lokalną, rozproszoną wiedzę (dostępna tylko im), by udoskonalić proces produkcji, a jednocześnie mogą korzystać z wiedzy zgromadzonej przez innych producentów, naśladując ich praktyki. Cały system koordynowany jest przez konsumentów eliminujących tych, którzy popełniają błędy, i wspierających tych obniżających ceny/zwiększających jakość. Co więcej, przekazywanie informacji jest tu maksymalnie uproszczone, ponieważ komunikowane są one nie w formie opisów, zasad czy regulaminów (które mają charakter jakościowy), ale cen — co umożliwia producentom obliczenie najbardziej efektywnych metod działania.

Podsumowanie dotychczasowych rozważań mieści tabela 1.

Tabela 1. Prywatna i państwowa opieka medyczna

\begin{tabular}{|c|c|}
\hline Prywatna opieka medyczna & Państwowa opieka medyczna \\
\hline dobrowolna & oparta na przymusie \\
\hline finansowana z wpłat konsumentów & finansowana $\mathrm{z}$ podatków \\
\hline $\begin{array}{l}\text { oparta na konkurencji między wieloma pro- } \\
\text { ducentami }\end{array}$ & oparta na monopolu \\
\hline $\begin{array}{l}\text { funkcjonuje mechanizm zysków i strat — pro- } \\
\text { ducenci produkujący dobro o niskiej jakości } \\
\text { lub wysokiej cenie bankrutują }\end{array}$ & $\begin{array}{l}\text { nie ma mechanizmu zysków i strat - nieefek- } \\
\text { tywne podmioty nie bankrutują }\end{array}$ \\
\hline $\begin{array}{l}\text { wiele podmiotów rozwiązuje problem, najlep- } \\
\text { sze rozwiązanie jest kopiowane (możliwość } \\
\text { wykorzystania rozproszonej wiedzy lokalnej) }\end{array}$ & $\begin{array}{l}\text { jeden producent arbitralnie decyduje, co i jak } \\
\text { ma być produkowane (korzystanie z rozpro- } \\
\text { szonej wiedzy lokalnej bardzo utrudnione) }\end{array}$ \\
\hline możliwość kalkulacji ekonomicznej & $\begin{array}{l}\text { nie ma kalkulacji ekonomicznej lub niedosko- } \\
\text { nała kalkulacja oparta na arbitralnie ustalo- } \\
\text { nych przez państwo cenach/punktach }\end{array}$ \\
\hline $\begin{array}{l}\text { ciągły proces innowacji (pozwala utrzymać } \\
\text { się na rynku) }\end{array}$ & $\begin{array}{l}\text { spowolniona innowacyjność, bezwładność } \\
\text { systemu (zmiany nie są konieczne, bo klienci } \\
\text { nie mają dokąd uciec) }\end{array}$ \\
\hline $\begin{array}{l}\text { biurokracja służy koordynacji procesu pro- } \\
\text { dukcyjnego (tylko tyle biurokracji, by móc } \\
\text { działać sprawnie i nie móc zostać pozwanym } \\
\text { przez konsumenta) }\end{array}$ & $\begin{array}{l}\text { biurokracja oddziela się od procesu produkcji } \\
\text { i staje się celem samym w sobie, „biurokracja } \\
\text { rozwija się niezależnie od potrzeb”, strata } \\
\text { czasu i zasobów na podporządkowanie się } \\
\text { narzucanym odgórnie regulacjom }\end{array}$ \\
\hline błędy mają charakter lokalny & błędy rozlewają się po całym systemie \\
\hline
\end{tabular}




\begin{tabular}{|l|l|}
\hline nie podlega wpływom politycznym & podległa wpływom politycznym \\
\hline $\begin{array}{l}\text { niepodatna na nepotyzm i korupcję (zatrud- } \\
\text { nianie niekompetentnych członków rodziny/ } \\
\text { znajomych i lepsze traktowanie „swoich” } \\
\text { możliwe, ale oznacza straty dla producenta) }\end{array}$ & $\begin{array}{l}\text { podatna na nepotyzm i korupcję (zatrudnianie } \\
\text { niekompetentnych członków rodziny/znajo- } \\
\text { mych i lepsze traktowanie „swoich” nie wiąże } \\
\text { się ze stratami, tracą pacjenci) }\end{array}$ \\
\hline $\begin{array}{l}\text { możliwość ukrywania wyników leczenia, sta- } \\
\text { tystyk i błędów lekarskich, ale istnieje zachęta } \\
\text { ekonomiczna dla najlepszych podmiotów do } \\
\text { transparentności }\end{array}$ & $\begin{array}{l}\text { nie ma ekonomicznego powodu, by przed- } \\
\text { stawiać wyniki leczenia, statystyki, błędy } \\
\text { lekarskie }\end{array}$ \\
\hline
\end{tabular}

Źródło: opracowanie własne

\subsubsection{Przykłady nieefektywności państwowej opieki medycznej}

W poprzednim paragrafie wskazaliśmy fundamentalne powody, dla których państwowa opieka medyczna działa nieefektywnie. Spróbujmy pokazać, w jaki sposób te fundamentalne kwestie manifestują się w postaci konkretnych problemów państwowej służby zdrowia.

1. Wyważenie relacji między „merytoryczną” pracą lekarzy a elementami administracyjnymi. Wobec niestosowania mechanizmu rynkowego w zapewnianiu jakości w państwowej służbie zdrowia bardzo dużą rolę odgrywają metody urzędnicze, czyli określanie formalnych warunków realizacji procedur, a następnie zbieranie szczegółowych raportów $\mathrm{z}$ ich wykonania, które trafiają $\mathrm{z}$ powrotem do urzędników przydzielających środki finansowe. Powoduje to konieczność produkowania przez lekarzy i pracowników administracyjnych szpitali olbrzymiej ilości dokumentacji ${ }^{17}$. W efekcie lekarze, którzy mają olbrzymią przewagę komparatywną w świadczeniu usług medycznych, tracą czas na „papierologię"18.

2. Ze względu na nieistnienie koordynującego mechanizmu rynkowego (ceny jako system przesyłania informacji i generowania zachęt) i oparcie się na odgórnym systemie nakazów i rozporządzeń państwo ma problemy z racjonalną alokacją zasobów: ustaleniem odpowiedniej liczby lekarzy praktykujących daną specjalizację, określeniem odpowiedniej ilości sprzętu oraz właściwym wykorzystaniem zarówno sprzętu, jak i zasobów ludzkich. Typowe problemy przyjmują tu następujący kształt: jest sprzęt, ale nie ma specjalistów; są specjaliści, ale nie ma sprzętu; są chirurdzy, ale nie ma anestezjologów; są pracownicy, ale nie ma pracy; jest za dużo pracy dla za małej liczby pracowników itp. Błędna alokacja zasobów

17 Przykładowo, z 20 minut wizyty u lekarza aż 16 to czynności organizacyjne, a tylko niecałe 4 minuty to czas na zbadanie i rozmowę z pacjentem. Zob. raport „E-zdrowie oczami Polaków” przygotowany przez firmę LekSeek Polska. Data dostępu: 3.01.2020, https://www.skarbiec.biz/gospodarka/uslugi/biurokracja-w-sluzbie-zdrowia-obniza-poziom-uslug.html.

18 Oczywiście także w warunkach rynkowych istnienie dokumentacji byłoby konieczne, jednak konkurujące na rynku podmioty doprowadziłyby (w procesie złożonych interakcji z innymi podmiotami rynkowymi, na przykład ubezpieczycielami, firmami akredytacyjnymi itp.) do określenia jej optymalnej ilości. 
— oprócz ograniczeń podaży — jest powodem istnienia jednego z najczęściej zauważanych problemów państwowej służby zdrowia, czyli kolejek.

3. Państwo ma problemy z ustaleniem właściwego kompromisu między bezpieczeństwem a efektywnością. Zbyt mała dbałość o bezpieczeństwo może narażać życie i zdrowie pacjenta, przesadna dbałość zmniejsza liczbę usług docierających do pacjentów. Wobec braku mechanizmów rynkowych państwo posługuje się systemem narzuconych odgórnie (a nie wypracowanych oddolnie, z wykorzystaniem lokalnej wiedzy) zasad bezpieczeństwa, które często są zbyt restrykcyjne, zbyt mało restrykcyjne, często zaś w ogóle nie są przestrzegane.

4. Państwo ma problem z określaniem, kto ma prawo do wykonywania konkretnych procedur medycznych. W polskim systemie prawo do wykonywania zawodu lekarza mają wyłącznie osoby, które ukończyły sześcioletnie państwowe studia, zdały państwowy egzamin i odbyły trzynastomiesięczny staż. W efekcie osoby te są powstrzymywane przez przynajmniej 7 lat od świadczenia jakichkolwiek usług medycznych (na pełne prawo do samodzielnego wykonywania części procedur konieczne jest dodatkowe 5 lat specjalizacji, co oznacza konieczność co najmniej dwunastoletniego przygotowania do świadczenia niektórych usług). Taka regulacja byłaby sensowna tylko przy założeniu, że wszystkie procedury wykonywane przez lekarzy wymagają sześcioletnich studiów i trzynastomiesięcznego stażu. Różne działania z zakresu opieki medycznej wymagają różnych kompetencji: całościowe prowadzenie pacjenta onkologicznego to coś innego niż przyjęcie kogoś, kto przyszedł do lekarza z zapaleniem gardła, i zapisanie mu leków, a jeśli kuracja nie zadziała, skierowanie go do laryngologa. W ładzie wolnorynkowym lekarze o wiele szybciej zdobywaliby kompetencje potrzebne, by świadczyć podstawowe usługi medyczne ${ }^{19}$, i dopiero potem opanowywaliby resztę wiedzy niezbędnej na dalszych etapach rozwoju zawodowego. Nowi lekarze wchodziliby na rynek „od dołu” (od najprostszych procedur), co pozwalałoby specjalistom zajmować się bardziej skomplikowanymi procedurami i racjonalizowałoby alokację zasobów.

5. Problemem państwowej edukacji jest nie tylko długość jej trwania, ale ipłynąca z braku konkurencji między podmiotami świadczącymi usługi oraz braku systemu cen - nieefektywność. Mimo bardzo długiego okresu edukacji młodzi lekarze przeważnie nie są przygotowani do świadczenia usług medycznych. Przykładowo, młodzi chirurdzy po rozpoczęciu pracy dopiero zaczynają uczyć się operować, dodatkowo mogą być powstrzymywani od rozpoczęcia pełnopraw-

19 Warto zauważyć, że istnieją różnice między państwami, dotyczące barier prawnych odnośnie do świadczenia usług medycznych przez osoby, które nie zdobyły dyplomu ukończenia studiów. Studenci medycyny w Polsce, chcąc dorobić w trakcie studiów, podejmują najczęściej prace niezwiązane z medycyną. W Niemczech studenci mogą dorobić, pomagając chirurgom przy operacjach (tak zwane trzymanie haków — „Hakenhalter”), dyżurując przy pacjentach, monitorując ich stan („Extrawache”), pomagając przy podstawowych zabiegach pielęgnacyjnych itp. Możliwość zarobkowania w szpitalu (pobieranie krwi, zabezpieczanie wydarzeń sportowych) pojawia się po 4 semestrach wraz ze zdanym egzaminem z przedmiotów przedklinicznych.

Ekonomia - Wroclaw Economic Review 26/1, 2020

(C) for this edition by CNS 
nej działalności przez starszych lekarzy, którzy uznają, że ich młodsi koledzy nie są jeszcze gotowi do samodzielnej pracy (oprócz troski o jakość znaczenie ma tu również chęć ograniczenia konkurencji). Wszystkie te problemy, obejmujące punkty $2-5$, powodują, że liczba osób praktykujących zawód lekarza jest sztucznie ograniczona, w efekcie czego: (a) pacjenci muszą dłużej czekać na wizytę do specjalisty, (b) zabiegi przesuwane są na późniejsze terminy, (c) lekarze poświęcają pacjentom mniej czasu, (d) lekarze są przepracowani i pracują nieefektywnie, popełniając błędy, (e) lekarze mają prawo żądać większych cen za wizyty/zabiegi (dotyczy to zarówno rynku prywatnego, jak i państwowych kontraktów) ${ }^{20}$. Wymienione problemy związane z ograniczaniem dostępu do zawodu lekarza dotyczą również innych zawodów medycznych, takich jak pielęgniarka, technicy laboratoryjni, technicy radiologii, fizjoterapeuci, ratownicy medyczni, farmaceuci itp. I tutaj liczba osób mogących pracować w zawodzie jest w sztuczny sposób zaniżana. Problemy te pogłębione są jeszcze przez to, że państwo ustala pewne arbitralne zasady, kto i jakie czynności medyczne może wykonywać. Część rzeczy, która mogłaby być wykonywana z powodzeniem przez personel niższego stopnia, w wyniku arbitralnych decyzji ustawodawców może być wykonywana wyłącznie przez lekarzy.

6. Państwo nie ma wystarczających zachęt ekonomicznych do wprowadzania innowacji. Jest mnóstwo technologicznych wynalazków, które mogłyby być natychmiast wprowadzone i doprowadzić do zrewolucjonizowania obszaru usług medycznych, by wymienić choćby takie innowacje, jak:

(a) digitalizacja historii choroby pacjenta. W Polsce dokumentacja medyczna dostępna jest najczęściej jedynie w formie papierowej (o ile wcześniejsze wizyty lub hospitalizacje nie odbyły się w tej samej placówce). Zdarza się, że pacjenci przy kolejnych hospitalizacjach nie są w stanie dostarczyć dokumentacji medycznej z powodu jej zagubienia. Dokumentacja jest często niskiej jakości — na przykład napisana niewyraźnie pismem odręcznym. Zamiast opierać się na obiektywnych, udokumentowanych źródłach, lekarze w wielu przypadkach muszą zadowolić się niepewnymi informacjami z trudem uzyskanymi od pacjenta;

(b) telemedycyna, czyli wykorzystanie technologii cyfrowego przesyłania informacji w medycynie, które może wydatnie ograniczyć koszty oraz umożliwić szybszą i lepszą pomoc medyczną (Svorny, 2017). Przykłady: konsultacje medyczne online, stetoskopy do samodzielnego użytku pacjenta rejestrujące zjawiska osłuchowe i wysyłające zapisane dźwięki do lekarza, ciśnieniomierze wysyłające wyniki na platformę dostępną dla lekarza, operacje z wykorzystaniem

20 Warto zauważyć, że punkty (a)-(d) niosą pośrednio konsekwencje. Przykładowo, konieczność czekania na wizytę u specjalisty lub zabieg istotnie wpływa na szansę wyleczenia choroby, dodatkowo eskalując koszty (zbyt długie oczekiwanie na usługę medyczną może doprowadzić na przykład do tego, że zamiast leczenia za pomocą leków konieczny będzie zabieg). To samo dotyczy ograniczonego czasu, który lekarze mogą poświęcić swoim pacjentom: pacjenci są badani pobieżnie, decyzje podejmowane bez namysłu, pochopnie, częściej zdarzają się błędy itp.

Ekonomia - Wroclaw Economic Review 26/1, 2020

(C) for this edition by CNS 
robotów operacyjnych prowadzone na odległość, wizyty online, coachowie zdrowia nadzorujący leczenie online/telefonicznie, inteligentne opatrunki wysyłające informacje o stanie rany itp.;

(c) wykorzystanie sztucznej inteligencji jako metody diagnostycznej i kontrolnej. Dotyczy to stawiania diagnozy na podstawie wywiadu, analizy badań obrazowych czy kontroli nad wykonywanymi operacjami;

(d) wykorzystanie danych statystycznych jako metoda kontroli nad lekarzami i instytucjami. Najbardziej trywialnym przykładem jest zbieranie i publikowanie statystyk udanych i nieudanych zabiegów wykonywanych przez konkretnych operatorów, co pozwalałoby z jednej strony na kontrolę tych lekarzy, z drugiej strony dałoby większą wiedzę pacjentom;

(e) technologie cyfrowego zapisu operacji. W Polsce nie nagrywa się przebiegu operacji chirurgicznych. Nagrywanie procedur medycznych może umożliwić nadzór nad jakością wykonywanych zabiegów, może być wykorzystane jako dokument $\mathrm{w}$ razie procesu sądowego, a także materiał do badań naukowych.

7. Państwo źle radzi sobie z profilaktyką oraz z opieką nad osobami, które zostały wyleczone, ale wymagają dalszego zainteresowania medycznego, czy szerzej - z kompleksowym podejściem do pacjenta. Zgoła odmiennie wyglądać będzie to w systemie prywatnym, w którym ubezpieczyciele będą bardzo zainteresowani, by ubezpieczający się żyli zdrowo, gdyż to będzie minimalizować wysokość wypłacanych odszkodowań.

8. Państwowi producenci zdrowia źle radzą sobie w kwestii tak zwanych umiejętności miękkich: komunikacji z pacjentem, właściwego stosunku emocjonalnego itp. Oprócz braku zachęt ekonomicznych problemem jest także to, że zarządzanie biurokratyczne niezbyt nadaje się do egzekwowania tego typu umiejętności.

9. Ze względu na eksternalizację kosztów leczenia mamy do czynienia z problemem nadkonsumpcji, w której efekcie niewymagający opieki medycznej pacjenci blokują do niej dostęp pacjentom wymagającym opieki.

10. Problemy z biurokratycznym zarządzeniem objawiają się również w kontekście problemów z (będącym pokłosiem niemożności korzystania z systemu cen) wycenianiem procedur, koniecznym do rozliczeń między państwem a podmiotami świadczącymi usługi zdrowotne. Owocuje to problemami takimi, jak: niepotrzebne hospitalizacje i przetrzymywanie pacjentów na oddziałach (gdy pieniądze ,idą za pacjentem"), unikanie przyjmowania problematycznych pacjentów (gdy za pacjentem ,idą koszty"), nieliczenie się z kosztami celem zabezpieczenia się przez lekarzy (na przykład przez zlecanie niepotrzebnej diagnostyki), preferowanie wysoko wycenianych procedur nad procedury nisko wyceniane (kosztem ogólnej efektywności systemu, a czasem także zdrowia pacjenta), fałszywe opisywanie procedur celem zwiększenia zysków, tendencja do stosowania uporczywej terapii itp.

11. I wreszcie to, że państwowa medycyna nie działa na zasadach rynkowych, tworzy zachętę u osób racjonujących opiekę medyczną do uzależniania dostępu do niej od „nieoficjalnych form opłat”. Bardziej jaskrawym przypadkiem są tu 
łapówki, mniej jaskrawym - uzależnianie dostępu do opieki od opłat wnoszonych na równoległym rynku prywatnym: pierwszeństwo w leczeniu zabiegowym, szpitalnym i dostępie do diagnostyki mają pacjenci, którzy leczą się prywatnie u lekarzy racjonujących dostęp do opieki medycznej.

Konsekwencją wszystkich tych problemów jest niska jakość opieki medycznej, niedobory (długie oczekiwanie na wizytę u specjalisty, krótkie wizyty, długie oczekiwanie na zabieg) oraz wysokie koszty funkcjonowania całego systemu. Wszystko to pozwala myśleć, że ze względu na wyższą efektywność systemu wolnorynkowego średnie koszty opieki medycznej byłyby w ładzie libertariańskim istotnie niższe niż w ładzie państwowym.

\subsection{Ekonomiczne zachęty do dbania o zdrowie w systemie państwowym i ładzie libertariańskim}

Kolejny powód, dla którego mamy prawo myśleć, że opieka medyczna byłaby w ładzie libertariańskim radykalnie tańsza, związany jest z ekonomicznymi zachętami do dbania o zdrowie, które produkowałby system CPOM. Argument ten streścić można następująco:

(1) przyczyny powstawania generujących koszty chorób są dwojakie: zależne i niezależne od działań jednostki;

(2) koszty opieki medycznej zależne od działań jednostki stanowią istotną część ogólnych kosztów opieki medycznej;

(3) ład wolnorynkowy — w przeciwieństwie do państwowego — stwarza odpowiednie zachęty ekonomiczne, by żyć zdrowo;

(4) ze względu na te zachęty w ładzie wolnorynkowym ludzie żyliby zdrowiej, co generowałoby niższe ogólne koszty opieki medycznej.

W systemie wolnorynkowym składki ubezpieczeniowe byłyby zróżnicowane ze względu na prawdopodobieństwo wystąpienia określonych kosztów leczenia. Ponieważ wysokość składki byłaby proporcjonalna do zsumowanego prawdopodobieństwa wystąpienia różnego rodzaju chorób, osoby, które nie dbałyby o zdrowie, zwiększałyby prawdopodobieństwo zachorowania, w związku z czym musiałyby płacić odpowiednio wyższe składki — dotyczyłoby to zarówno podstawowego ubezpieczenia zdrowotnego (także z gwarancją odnawialności), jak i ubezpieczenia od zmiany statusu zdrowotnego. Jesteśmy w stanie określić wiele czynników, które istotnie zwiększają ryzyko zachorowania na wielką liczbę poważnych chorób. Wiedzę tę firmy ubezpieczeniowe przemieniłyby w system zniżek, które przysługiwałyby tym, którzy żyją zdrowo. Ubezpieczyciele różnicowaliby wysokość składek zależnie od tego, czy pacjenci:

(a) przestrzegają zasad zdrowego żywienia,

(b) dbają o utrzymanie prawidłowej masy ciała,

(c) zapewniają organizmowi odpowiednio dużo ruchu, 
(d) dbają o odpowiednią długość snu,

(e) dbają o możliwie niski poziom stresu,

(f) nie nadużywają alkoholu,

(g) nie nadużywają nikotyny,

(h) nie zażywają/nie nadużywają narkotyków,

(i) dbają o higienę,

(j) poddają się regularnym badaniom lekarskim,

(k) szybko reagują na pierwsze symptomy chorób i zgłaszają je lekarzom,

(1) w trakcie leczenia (szczególnie w przypadku ciężkich chorób) poddają się zaleceniom lekarskim,

(m) nie angażują się w niepotrzebne działania, które niosą z sobą duże ryzyko wystąpienia uszczerbku na zdrowiu (sporty ekstremalne, ryzykowne kontakty seksualne, brawurowe zachowania),

(n) nie wykonują zagrażającej życiu i zdrowiu pracy,

(o) unikają ekspozycji na negatywne czynniki środowiskowe (zanieczyszczenie powietrza itp. $)^{21}$.

Ponieważ osoby, które ignorowałyby ogólnie uznane zasady zdrowego życia, musiałyby (1) płacić więcej za opiekę zdrowotną w formie bezpośrednich opłat (koszty wizyt u lekarzy, leków, badań itp.), (2) płacić wyższe składki ubezpieczeniowe (zarówno PUZ, UZS, UZGO, jak i innych typów ubezpieczeń), istniałaby znaczna zachęta ekonomiczna, by żyć zdrowo. Ponieważ ludzie żyliby zdrowiej, byliby zdrowsi, w związku z czym istniałaby mniejsza potrzeba kupowania opieki medycznej, a to oznacza, że jej koszty by się zmniejszyły. Kiedy mówimy o kosztach opieki medycznej, myślimy zwykle o cenach usług medycznych. Ale kupowanie usług medycznych to tylko jedna (wcale nie najlepsza) z metod zapewniania sobie zdrowia. Jednostka nie ma wpływu na istniejące na rynku ceny, może jednak radykalnie zmniejszyć prawdopodobieństwo konieczności nabywania usług medycznych.

Jednym z największych problemów wywołanych przez instytucję państwowej służby zdrowia jest problem pokusy nadużycia. Ponieważ jednostki wiedzą, że jeśli popadną w kłopoty zdrowotne, państwo przeznaczy teoretycznie nieograniczoną ilość środków, by ich z tych problemów ratować, ekonomiczna zachęta, by unikać

${ }^{21}$ W jaki sposób ubezpieczyciele mogliby upewnić się, że ich pacjenci żyją w zgodzie z przedstawionymi zasadami zdrowego życia? Część z tych kwestii da się określić w łatwy sposób w formie prostych badań, na przykład badań krwi, ciśnienia, masy ciała, BMI, procentu tkanki tłuszczowej, badania wysiłkowego pracy serca, badania pojemności płuc itp. Inne zasady dałoby się sprawdzić w formie wyrywkowych kontroli - firma ubezpieczeniowa mogłaby na przykład wzywać raz na jakiś czas swych klientów, by zrobić im badanie krwi i moczu, które pozwalałyby na przykład wykryć, czy nadużywają alkoholu lub stosują narkotyki. I wreszcie, łamanie części z tych zasad nie tylko powoduje wzrost prawdopodobieństwa zachorowania na określoną chorobę, ale po prostu pogarsza ogólny stan zdrowia. Innymi słowy firma ubezpieczeniowa nie musiałaby wiedzieć, czy pacjent żyje zdrowo, ale badałaby, w jakim stopniu jest zdrowy. Z biegiem czasu ubezpieczyciele byliby coraz lepsi w ocenianiu, czy dana jednostka żyje zdrowo.

Ekonomia - Wroclaw Economic Review 26/1, 2020

(C) for this edition by CNS 
zachowań zwiększających ryzyko zachorowania, się zmniejsza. Zjawisko to wydawać się może kontrintuicyjne, ostatecznie przecież nikt nie chce być chory. Czy fakt, że państwo leczy nowotwory, sprawia, że ludzie nie martwią się zachorowaniem na nowotwór? Z pewnością nie. Niemniej jednak im mniejszą część kosztów choroby ponieść będzie musiała jednostka, tym mniejsza będzie jej zachęta, by choroby unikać. Koszty choroby to nie tylko koszty związane z cierpieniem nią wywołanym, ale także koszty leczenia. Jeżeli państwo zdejmuje z nas tę drugą część kosztów, widmo zachorowania staje się mniej straszne. Ktoś, kto wie, że gdy zachoruje wskutek palenia tytoniu i picia alkoholu, to zostanie za darmo wyleczony, ma mniejszą zachętę, by unikać tych ryzykownych zachowań, niż ktoś, kto prócz męki choroby będzie musiał ponieść pełne koszty leczenia (czy to w postaci zwiększonej składki ubezpieczeniowej, czy w postaci zwiększonych opłat bezpośrednich ${ }^{22}$ ). W systemie prywatnej medycyny wszystkie koszty choroby byłyby zinternalizowane, dlatego jednostka miałaby maksymalną zachętę ekonomiczną, by unikać choroby. W systemie państwowym istotna część kosztów jest zeksternalizowana, dlatego ludzie, podejmując życiowe wybory, biorą pod uwagę tylko część związanych z nimi kosztów, co często okazuje się niewystarczające, by zachęcić ich do dbania o zdrowie.

\subsubsection{Natychmiastowe i odsunięte w czasie koszty niezdrowego życia}

Fizyczne koszty choroby — w przeciwieństwie do kosztów opłacania składki ubezpieczeniowej - są odsunięte w czasie. Fakt, że niewłaściwe odżywianie może wywołać za 20 lat chorobę, dla wielu osób będzie miał mniejszą siłę przekonywania niż to, że niewłaściwe odżywianie sprawi, że już teraz będziesz musiał płacić wyższą składkę ubezpieczeniową. Problem niezdrowego życia jest więc problemem wysokiej preferencji czasowej. Ludzie wybierają zestaw „aktualna przyjemność/aktualne niecierpienie + potencjalne duże cierpienie w przyszłości” niż zestaw ,aktualne małe cierpienie/bez przyjemności + bez potencjalnego cierpienia w przyszłości”. Dokładając do pierwszego zestawu wyższą składkę ubezpieczeniową, jesteśmy w stanie skłonić część jednostek, by wybrały drugi zestaw i zaczęly żyć zdrowo. W systemie libertariańskim zachęta ekonomiczna do zdrowego życia miałaby więc nie tylko mglisty kształt potencjalnej choroby, ale bardzo realny i dotkliwy koszt większych kosztów ubezpieczenia i wyższych opłat bezpośrednich już teraz.

\subsubsection{Ryzykowne zachowania}

Przeprowadzona analiza dotyczy także wszelkiego rodzaju ryzykownych zachowań. Osoby jeżdżące na motocyklach, uprawiające sporty ekstremalne i angażujące się w inne działania grożące ponadprzeciętnymi kosztami opieki medycznej

${ }^{22}$ Dotyczyłoby to również osób, które nie miałyby pieniędzy na leczenie i musiałyby liczyć na pomoc najbliższych i pomoc charytatywną. Z pewnością najbliżsi i prywatne instytucje charytatywne chętniej pomagałyby osobom, które zrobiły wszystko, by być zdrowymi, ale zachorowały mimo to, niż osobom, które robiły wszystko, by zachorować (na przykład pijąc alkohol czy spożywając narkotyki). 
musiałyby płacić wyższe składki ubezpieczeniowe. Standardowe ubezpieczenie prawdopodobnie zawierałoby klauzulę, że nie pokrywa ono leczenia w wyniku wypadków na motocyklu, ubezpieczenie zaś, które pokrywałoby takie wypadki, byłoby odpowiednio wyższe. W efekcie ludzie angażowaliby się w takie działania mniej chętnie niż dziś, ci zaś, którzy by się angażowali, sami ponosiliby ich koszty, nie przerzucając ich na innych. Jeszcze radykalniej wyglądałaby sytuacja w przypadku narkotyków lub nadużywania alkoholu — ubezpieczyciel mógłby na przykład zastrzegać, że terapie będące konsekwencją spożycia narkotyków nie będą objęte ubezpieczeniem, co radykalnie zwiększałoby koszty ich zażywania ${ }^{23}$.

\subsubsection{Profilaktyka}

Wskazywaliśmy, że internalizacja kosztów leczenia powodowałaby, że pacjenci mieliby znaczną zachętę ekonomiczną, by dbać o zdrowie. Troska o zdrowie pacjenta pojawiłaby się również po stronie ubezpieczycieli. Ubezpieczyciel potrafiacy przekonać klientów, którzy wykupili u niego ubezpieczenie, by żyli zdrowo, będzie wydawał mniej pieniędzy na ich leczenie. Dodatkowo będzie mógł obniżyć składki, dzięki czemu przyciągnie nowych klientów. Rozważmy kwestię przestrzegania zaleceń lekarskich w trakcie leczenia przewlekłych chorób. Badania wskazują (będzie o tym jeszcze mowa), że niestosowanie się do zaleceń lekarskich eskaluje koszty leczenia. Ubezpieczyciel będzie więc szukać wszelkich metod, by wymóc na pacjencie stosowanie się do zaleceń, co pozwoli obniżyć mu sumę wypłat. Kini i Ho wskazują, że stosowanie preparatów złożonych — zawierających kilka substancji w jednej tabletce — przyczynia się do poprawy przestrzegania zaleceń terapeutycznych o $10 \%$, dostępność do konsultacji farmaceutycznych o 15\%, a przypomnienie o konieczności przyjmowania leków (na przykład telefoniczne) powoduje wzrost przestrzegania zaleceń terapeutycznych o 33\% (Kini, Ho, 2018). Skoro tak trywialne rozwiązanie jak telefoniczne przypomnienie o braniu leków może zaoszczędzić ubezpieczycielowi spore kwoty pieniędzy, należy przypuszczać, że ubezpieczyciele (wraz z lekarzami i placówkami zdrowia) stworzyliby wydajny system profilaktyczny, który skłaniałby klientów do dbania o zdrowie.

Może się wydawać, że jeśli pacjenci byliby ubezpieczeni w danej firmie na krótki okres (na przykład rok), ubezpieczyciel nie miałby odpowiedniej zachęty ekonomicznej, by rozwijać programy profilaktyczne. Istnieje jednak kilka powodów, dla których ewentualny krótki czas obowiązywania umów nie stałby w sprzeczności z rozwojem działań profilaktycznych. Po pierwsze, to, że umowy zawierano by na przykład na rok, nie oznacza, że ludzie po roku zmienialiby ubezpieczycieli. Ubezpieczyciela zmieniałoby się prawdopodobnie rzadko, a on sam robiłby wszystko, by do zmiany nie doszło (konkurencyjność rynku gwarantowałaby sama możliwość zmiany ubezpieczyciela i zmieniający ubezpieczycieli konsumenci marginalni). Po-

${ }^{23}$ Wszystkie te zachęty działałyby najbardziej oczywiście na najbiedniejszych, dla których składka zdrowotna stanowiłaby istotną część ich miesięcznych wydatków. Byłoby to doskonałą zachętą, by o zdrowie dbali ci, którzy mają z nim aktualnie największy problemem - ludzie biedni.

Ekonomia - Wroclaw Economic Review 26/1, 2020

(C) for this edition by CNS 
nieważ więc mimo jednorocznych umów klienci zostawaliby z ubezpieczycielami dłużej (na przykład na 7-8 lat), byłby to wystarczający okres, by ubezpieczyciele wdrażali rozwinięte programy profilaktyczne, które obejmowałyby prawie wszystkie istotne zagrożenia zdrowotne. Po drugie, klienci mogliby przystępować do organizowanych przez zewnętrzne podmioty wieloletnich programów profilaktycznych, w których udział obniżałby wysokość składek ubezpieczeniowych, co rozwiązywałoby „problem krótkiej perspektywy czasowej”. Po trzecie, w przypadku ubezpieczenia w modelu Cochrane'a (PUZ + UZS) ubezpieczyciel miałby dodatkowy interes w tym, by jego pacjent był „w ogólnie dobrym stanie”, gdyż gdyby obarczony chorobą pacjent zdecydował się na zmianę ubezpieczyciela, porzucony ubezpieczyciel musiałby rozliczyć się z nowym ubezpieczycielem, wpłacając na specjalne konto ubezpieczeniowe środki, z których pokrywana byłaby różnica między typowymi składkami zdrowotnymi a składkami powiększonymi w wyniku zaistniałej choroby. Ponieważ stosowanie się do zasad zdrowego życia zwiększa szansę na pomyślne przejście nabytej choroby (od której ubezpieczałoby UZS), „przekazując” innej firmie pacjenta, który stosował się do tych zasad, porzucony ubezpieczyciel przelewałby na jego konto odpowiednio mniejszą kwotę.

Ostatecznie konkurencję rynkową wygrają firmy, które zaproponują produkty minimalizujące konieczność korzystania z usług medycznych w wyniku maksymalnego skupienia się konsumentów na zdrowym stylu życia. Tym samym rynek usług medycznych zmieniłby się w rynek zdrowia (nie sprzedajemy leczenia, sprzedajemy zdrowie, leczenie jest tylko jedną z możliwości zapewnienia klientowi zdrowia). Przewidywania te skontrastować należy z systemem państwowym, w którym poszczególne podmioty nadzorujące/produkujące opiekę medyczną nie dysponują wystarczającymi zachętami ekonomicznymi, by skłaniać pacjentów do dbania o zdrowie. Należy również zauważyć, że ponieważ ubezpieczyciel, który potrafi dokładniej ocenić prawdopodobieństwo wystąpienia zdarzenia, może zanotować większy zysk, firmy ubezpieczeniowe byłyby bardzo zainteresowane badaniami, które pozwalałyby określić, jakie czynniki i w jakim stopniu wpływają na możliwość zapadnięcia na różne choroby, co zastymulowałoby ten obszar wiedzy.

\subsubsection{Kultura zdrowia}

Zwiększone zainteresowanie dbałością jednostek o zdrowie mogłoby doprowadzić do wytworzenia się kultury zdrowia. Ludzie zaczęliby w większym stopniu poszukiwać wiedzy na temat zdrowego życia. Początkowo zmiany dotyczyłyby najbardziej świadomych osób, ale z biegiem czasu — w formie mód, zwyczajów, dzięki dostępności produktów — byłyby wdrażane przez mniej świadome części społeczeństwa. Przykładowo, zwiększenie zainteresowania zdrowym żywieniem powoduje zwiększenie nań popytu, co z kolei prowadzi do obniżenia cen zdrowych produktów i zwiększenia cen produktów niezdrowych, równolegle do tego zachodzić będzie proces zmiany nawyków żywieniowych. To, że ludzie 
zaczęliby poważnie traktować swoje zdrowie, przełożyłoby się także na wzrost świadomości dotyczącej znaczenia czynników środowiskowych. Ludzie bardziej przejmowaliby się zanieczyszczeniem powietrza, gleb i wody i domagaliby się wprowadzenia polityk, które ograniczyłyby te negatywne zjawiska ${ }^{24}$.

\subsubsection{Jak istotne są czynniki zależne od pacjenta?}

W tym miejscu zapytać musimy: jak istotną część kosztów medycznych tworzą koszty zależne od stylu życia pacjenta? Na to pytanie próbował odpowiedzieć w 1974 roku Marc Lalonde, ówczesny minister zdrowia Kanady, w raporcie $A$ New Perspective on the Health of Canadians (Lalonde, 1974). Czynniki mające wpływ na stan zdrowia populacji podzielono na cztery grupy znane pod nazwą pól Lalonde'a: (1) obszar biologii i genetyki, (2) obszar zachowań i stylu życia, (3) obszar środowiskowy (do którego zaliczono czynniki społeczne, ekonomiczne, kulturowe i fizyczne) oraz (4) obszar organizacji systemu ochrony zdrowia. Według ustaleń autorów największy wpływ na zdrowie ludności ma styl życia (53\%), w tym aktywność fizyczna, sposób odżywiania się, umiejętności radzenia sobie ze stresem, stosowanie używek (nikotyna, alkohol, środki psychoaktywne) oraz zachowania seksualne. Wpływ środowiska fizycznego (czyste powietrze i woda, zdrowa i bezpieczna szkoła oraz zakład pracy) oszacowano na mniej więcej $21 \%$. Czynnikom genetycznym przypisano szesnastoprocentowy wpływ na zdrowie człowieka. Opiece medycznej (jej strukturze, organizacji, funkcjonowaniu czy też dostępności do świadczeń medycznych) przypisano jedynie dziesięcioprocentowy wpływ na zdrowie ludności. Nie musimy upierać się, że szacunki Lalonde'a są bardzo ścisłe, przygotowany przez niego raport wskazuje jednak na ważny aspekt: czynniki zależne od pacjenta pełnią niezwykle istotną funkcję w kontekście zdrowia jednostki. Jeśli ustalenia Lalonde'a byłyby prawdziwe, żyjąc w zdrowy sposób, społeczeństwo mogłoby osiągnąć ten sam efekt zdrowotny, płacąc na służbę zdrowia o połowę mniej.

Przyjrzyjmy się kosztom związanym z poszczególnymi ludzkimi zachowaniami mającymi wpływ na zdrowie. Według szacunków Cawleya i Meyerhoefera koszty leczenia wygenerowane przez otyłość w 2005 roku w USA wyniosły 209,7 mld dolarów, co stanowiło 20,6\% wszystkich wydatków na opiekę zdrowotną (Cawley, Meyerhoefer, 2012). Inne badanie porównywało średnie roczne koszty bezpośredniej opieki medycznej u pacjentów kontrolujących poziom glukozy we krwi w przebiegu cukrzycy, co przejawiało się w wartości hemoglobiny glikowanej poniżej 7\%, z grupą pacjentów niedostatecznie kontrolujących swoją chorobę, a u których poziom hemoglobiny glikowanej był wyższy niż 7\%. Okazało się,

${ }^{24}$ Zauważmy na marginesie, że osoby żyjące w zanieczyszczonych rejonach płaciłyby wyższe składki ubezpieczeniowe, co miałoby dwojakie konsekwencje: po pierwsze, wywierałyby one nacisk na rządzących, by rozwiązali uderzające w mieszkańców ekonomicznie problemy ekologiczne, po drugie, marginalni konsumenci przeprowadzaliby się do obszarów mniej zanieczyszczonych, co również — na zasadzie ,głosowania nogami” — zwiększałoby presję, by zarządzający tymi obszarami zareagowali na problemy związane z zanieczyszczeniem.

Ekonomia - Wroclaw Economic Review 26/1, 2020

(C) for this edition by CNS 
że roczne koszty opieki nad pacjentami, którzy nie kontrolowali poziomu glukozy, były o 2713 dolarów wyższe od rocznych kosztów opieki nad pacjentami niezaniedbującymi leczenia. Kiedy porównano grupę pacjentów utrzymujących hemoglobinę glikowaną poniżej 7\% przez 3 lata, z grupą, której to się nie udało, różnica w kosztach opieki medycznej wynosiła aż 5214 dolarów rocznie (Juarez et al., 2013). Nieprzestrzeganie zaleceń terapeutycznych przez pacjentów generuje według szacunków dający się uniknąć koszt 100-300 mld dolarów, co odpowiada od 3 do 10\% wydatków na zdrowie (Iuga, McGuire, 2014). Według innych opracowań w grupie dorosłych pacjentów z chorobami przewlekłymi 30-50\% wszystkich zalecanych leków nie jest przyjmowanych przez pacjentów, co przyczynia się do 125 tys. zgonów rocznie i odpowiada za 10\% wszystkich hospitalizacji (Kini, Ho, 2018). Palenie papierosów stanowi uznany czynnik ryzyka wielu nowotworów oraz ważny czynnik ryzyka sercowo-naczyniowego. Palenie ma również wpływ na skuteczność terapii w przypadku osób, które już zachorowały — palacze między innymi wykazują oporność na leki przeciwnowotworowe. W przypadku niektórych terapii ryzyko niepowodzenia rośnie u palaczy o $60 \%$. Średni dodatkowy koszt leczenia osoby, która nie zareagowała na pierwotną terapię przeciwnowotworową, szacowano na 100 tys. dolarów. Leczenie palacza jest średnio o 10,7 tys. dolarów droższe niż leczenie osoby niepalącej. W skali USA daje to sumę ponad 3,4 mld dolarów rocznie (Warren et al., 2019).

Widzimy więc, jak duże jest pole do redukcji kosztów w przypadku odejścia od nieefektywnego systemu państwowego, który wyeliminował takie rynkowe mechanizmy redukcji kosztów, jak: zróżnicowanie stawek za ubezpieczenie zdrowotne w zależności od czynników związanych ze stylem życia, konkurencja wśród ubezpieczycieli próbujących zminimalizować koszty związane z niezdrowym stylem życia wśród ubezpieczanej przez nich populacji czy internalizacja kosztów opłat bezpośrednich.

\subsection{Ludzie byliby bogatsi, więc opieka medyczna byłaby relatywnie tańsza}

Kolejnym powodem, dla którego możemy przypuszczać, że koszty opieki medycznej byłyby w ładzie libertariańskim niższe, jest to, że ład ten byłby bardziej produktywny od systemu państwowego. Ponieważ ludzie byliby bogatsi, relatywne koszty opieki medycznej by się zmniejszyły. Nie będziemy w tym miejscu dowodzili prawdziwości hipotezy mówiącej, że przeciętna jednostka w ładzie libertariańskim byłaby bogatsza od przeciętnej jednostki w ładzie państwowym — jest to część debaty, która ciągnie się od początków nowożytnej ekonomii. Niemniej jednak czytelnik o poglądach wolnorynkowych może uznać go za jeszcze jeden argument wspierający tezę, że istnienie całkowicie prywatnej służby zdrowia jest możliwe. 
W tym miejscu należy zwrócić uwagę na jeszcze jedną kwestię. Fundamentalna różnica między ładem libertariańskim a systemem państwowym polega na tym, że w tym pierwszym jednostka samodzielnie decyduje, w jaki sposób spożytkować zarobione przez siebie pieniądze, a w tym drugim duża część dochodów jest jej odbierana i przeznaczana do finansowania różnego rodzaju państwowych projektów. Z dużym uproszczeniem można powiedzieć, że w ładzie libertariańskim jednostka sama decyduje, co znajdzie się w jej koszyku dóbr, w systemie zaś państwowym decyduje jedynie o 50-65\% zawartości koszyka. W ładzie libertariańskim jednostki miałyby więc o wiele większą elastyczność odnośnie do swoich wydatków medycznych. Osoby (czy rodziny) w trudniejszej sytuacji zdrowotnej mogłyby przeznaczać większą część swoich zasobów na opiekę medyczną, rezygnując $\mathrm{z}$ wydatków na inne formy konsumpcji.

\subsection{Koszty opieki medycznej w ładzie libertariańskim - podsumowanie}

Wszystkie te czynniki - (1) niewydolny ekonomicznie system centralnego planowania, w którym podmioty produkujące usługi medyczne nie mają zachęt, by obniżać koszty i zwiększać jakość, (2) niestosowanie zachęt ekonomicznych, by dbać o zdrowie oraz (3) ogólny zły stan gospodarki kraju obniżający siłę nabywczą jednostek — pozwalają myśleć, że koszty państwowej opieki medycznej są istotnie zawyżone i że w ładzie wolnorynkowym byłyby one radykalnie niższe. W związku z tym mamy prawo liczyć, że praktycznie każdego byłoby stać na wykupienie ubezpieczenia zdrowotnego i uiszczanie raz na jakiś czas bezpośrednich opłat na wydatki medyczne ${ }^{25}$.

\section{Opieka medyczna dla osób nieposiadających środków na zakup usług medycznych}

Co z osobami, których nie byłoby stać na opłacenie opieki medycznej? Rozpocznijmy od określenia, kto mógłby należeć do tej grupy. Byłyby to:

${ }^{25}$ Należy brać pod uwagę, że osoby najbiedniejsze otrzymywałyby opiekę medyczną niższej jakości — jeśli nie w kontekście samych procedur medycznych, to przynajmniej w komforcie przechodzenia przez proces leczenia. Prawdopodobnie wytworzyłby się jakiś system zróżnicowania jakości usług medycznych. Zróżnicowanie jakości nie musi dotyczyć procedur o znaczeniu medycznym, może obejmować na przykład dostępność terminów, klimatyzację, dodatkowe udogodnienia, własną salę zamiast sali wieloosobowej z uciążliwymi pacjentami, lepszą obsługę pielęgniarską, lepsze jedzenie itp. W Singapurze oddziały szpitalne mają przypisane kategorie komfortu A, B1, B2+, B2 i C na podstawie poziomu dodatkowych udogodnień i komfortu dla pacjenta. Na przykład w klasie C nie ma klimatyzacji i nie można wybrać sobie lekarza prowadzącego, podczas gdy w wyższych klasach te udogodnienia są dostępne. Im wyższa klasa, tym mniejszy poziom państwowego dofinansowania do pobytu opłacanego z indywidualnego konta oszczędnościowego na wydatki medyczne, do którego prowadzenia obywatele Singapuru są zobligowani przez państwo (Massaro, Wong, 1995).

Ekonomia - Wroclaw Economic Review 26/1, 2020

(C) for this edition by CNS 
(1) dzieci, które urodziły się z bardzo poważnymi chorobami, w związku z czym wymagają dużych nakładów na opiekę medyczną od samego urodzenia;

(2) dzieci rodziców, których nie stać na ich ubezpieczenie;

(3) dzieci, których rodzice z jakichś względów nie chcieliby ich ubezpieczyć;

(4) osoby niepełnosprawne - umysłowo lub fizycznie (w tym osoby, które zachorowały na jakąś ciężką, przewlekłą chorobę) — które nie są w stanie na siebie zarabiać;

(5) zdrowe osoby, które z jakichś względów nie byłyby w stanie - mimo wysiłków — zarobić na ubezpieczenie zdrowotne.

Problem osób z grupy (1) mógłby być rozwiązany z zastosowaniem ubezpieczeń prenatalnych, o których mówiliśmy we wcześniejszych paragrafach, jak też dzięki pomocy charytatywnej. Problem osób z grup (2), (4) i (5) musiałby być rozwiązany dzięki dobrowolnej pomocy ze strony osób trzecich. Pomoc ta byłaby świadczona przez rodziny, bliskich, lokalną wspólnotę czy zajmujące się takimi przypadkami fundacje charytatywne. Ponieważ opieka medyczna byłaby tańsza niż w systemie państwowym, a ludzie zamożniejsi, możemy przewidywać, że ilość pieniędzy, którymi dysponowałyby takie fundacje, byłaby wystarczająca. Dodatkowo prywatne instytucje charytatywne przeważnie świadczą pomoc bardziej efektywnie niż państwo (Edwards, 2007). Pomoc charytatywna mogłaby być również świadczona przez lekarzy i innych pracowników służby zdrowia pro bono. Pierwsze szpitale w USA powstawały właśnie jako instytucje finansowane dobrowolnie w ramach działalności dobroczynnej (Stevens, 1989). Działania takie byłyby podejmowane zarówno z pobudek altruistycznych, jak i z dbałości o wizerunek danej instytucji.

Problematyczna w tym kontekście jest grupa (3) - dzieci, których rodzice nie chcieliby ubezpieczyć. Jakie mogłyby być tego powody? Przede wszystkim ignorancja (niezrozumienie, jak ważne jest ubezpieczenie medyczne) oraz chęć uniknięcia kosztów płacenia składki medycznej, wynikająca z ignorowania potrzeb dziecka (co mnie obchodzi, że dziecko zachoruje) bądź będąca rodzajem „odwróconego hazardu” (większość dzieci nie choruje na poważne choroby, więc moje dziecko też nie zachoruje ${ }^{26}$ ). $\mathrm{Z}$ istnieniem tego typu sytuacji mogą się wiązać poważne problemy. Jeżeli instytucje charytatywne pomagałyby również takim dzieciom (na przykład proponując, że zapłacą za ich ubezpieczenie), dla części rodziców byłby to sygnał, że nie warto samemu płacić za ubezpieczenie ich dzieci. W konsekwencji liczba niepłacących rodziców by rosła i zasoby fundacji charytatywnych okazałyby się niewystarczające. Fundacje charytatywne musiałyby więc niechętnie spoglądać na osoby nieubezpieczające dzieci. Ale czy wtedy nieubezpieczone dzieci nie płaciłyby za grzechy rodziców? Rozwiązaniem tego problemu mogłaby być groźba odebrania praw rodzicielskich rodzicom, którzy

${ }^{26}$ Innym, mniej istotnym powodem mogłaby być nieufność wobec mainstreamowej medycyny i chęć opierania się na różnych wersjach medycyny alternatywnej. 
nie są w stanie zapewnić opieki medycznej dzieciom. Jeśli prawo do wychowywania dzieci miałoby być odbierane rodzicom z powodu niewykupienia ubezpieczenia, rodzice ci mogliby twierdzić — i mieliby prawdopodobnie rację - że jest to pogwałcenie ich praw. Problem ten można byłoby rozwiązać w ten sposób, że prawo takie byłoby odbierane rodzicom dopiero w momencie zachorowania dziecka, gdy rodzice nie byliby w stanie zdobyć wystarczających pieniędzy na jego leczenie. Byłby to przekonywający dowód na to, że rodzice nie są w stanie zapewnić dziecku potrzebnej opieki. Wytwarzałoby to silną presję na rodzicach, by ubezpieczyć dziecko. Niestety część rodziców mogłaby liczyć, że ich dziecko nie zachoruje, a gdy jednak zachoruje, przyjąć odebranie im praw do dziecka z ulgą — jako zwolnienie z konieczności opiekowania się chorym dzieckiem. Jednym z rozwiązań tego problemu mogłoby być obciążenie rodziców kosztami zmiany statusu zdrowotnego.

\subsection{Problem osób nieubezpieczonych}

W tym miejscu wspomnieć musimy o jeszcze jednej grupie, a mianowicie ludziach, którzy byliby w stanie zarobić na ubezpieczenie zdrowotne, ale nie wykupywaliby $\mathrm{go}^{27}$. Powodem byłaby ignorancja, wysoka preferencja czasowa i wiara w to, że choroba ich ominie. Części tych hazardzistów zdrowia udawałoby się przejść przez życie bez rujnujących budżet chorób, część jednakże zapadałaby w końcu na zdrowiu. Co działoby się z takimi osobami? Odpowiedź na to pytanie nie jest łatwa. Rozważmy dwie biegunowo przeciwstawne możliwości: (a) fundacje charytatywne będą pomagały takim osobom, (b) fundacje charytatywne nie będą pomagały także takim osobom.

Rozwiązanie (a) jest problematyczne. Jeśli fundacje miałyby płacić za leczenie wszystkich nieubezpieczonych, część społeczeństwa mogłaby przestać się ubezpieczać i próbować ,jechać na gapę" na pomocy świadczonej przez te fundacje (bycie hazardzistą zdrowia okazywałoby się strategią wygrywającą). Z kolei rozwiązanie (b) - pozostawienie tych osób samych sobie - wielu osobom ze względów moralno-emocjonalnych może wydać się nie do przyjęcia. Niemniej jednak przemawiają za nim także istotne argumenty. $Z$ ekonomicznego punktu widzenia konsekwencją takiego podejścia byłoby wytworzenie znacznej presji na osoby chcące zaoszczędzić na ubezpieczaniu się. Z moralnego punktu widzenia pytać można, czy mamy obowiązek pomagać osobom, które same doprowadziły się do stanu, w którym pomoc stała się konieczna? Ostatecznie, nie można twierdzić, że osoby, które z własnej woli się nie ubezpieczyły, były pozbawione

27 Należy liczyć się z możliwością, że taka grupa byłaby liczna — Bundorf i Pauly wskazują, że od jednej czwartej do trzech czwartych osób nieubezpieczonych w USA stać na ubezpieczenie (Bundorf, Pauly, 2006). Jak wskazywaliśmy, koszty opieki medycznej byłyby radykalnie tańsze w systemie prywatnym, dlatego można się spodziewać, że liczba nieubezpieczonych nie byłaby tak duża. 
dostępu do opieki medycznej, czy raczej że były pozbawione możliwości bycia zdrowymi. Miały one taką możliwość, ale zdecydowały się (z jakichś względów) z niej nie skorzystać.

Być może nie ma potrzeby wybierania między silnymi wersjami rozwiązania (a) i (b). Z pewnością konieczna byłaby pewna nieczułość na problemy hazardzistów zdrowia, która nie pozwalałaby im bezkarnie korzystać z miłosierdzia innych, jednak trudno sobie wyobrazić, by takie osoby zostały pozostawione zupełnie same sobie. Prawdopodobnie jakaś opieka medyczna do nieubezpieczonych by docierała, niemniej jednak byłaby to opieka o niższej jakości, trudna do zdobycia i być może wymagająca różnego rodzaju wyrzeczeń.

\section{Jakość usług medycznych w systemie CPOM}

Przechodzimy do ostatniego tematu, jakim jest jakość usług medycznych na wolnym rynku. Skupimy się przede wszystkim na problemie jakości usług świadczonych przez lekarzy, ta kwestia wydaje się bowiem najbardziej problematyczna. Aktualnie kontrolą jakości usług medycznych zajmuje się państwo. Usługi medyczne świadczyć mogą tylko osoby, które spełniły określone przez państwo wymagania (ukończyły studia, zdały państwowy egzamin, przeszły staż, zdobyły specjalizację pozwalającą świadczyć bardziej specjalistyczne usług itp.). W ładzie wolnorynkowym każdy mógłby świadczyć usługi medyczne, nie istniałyby żadne regulacje państwowe w tym zakresie. Taki stan rzeczy może budzić niepokój. Czy nie oznaczałoby to pojawienia się na rynku wielkiej liczby niekompetentnych lub nieuczciwych lekarzy (czy zwykłych szarlatanów), którzy nadużywaliby zaufania niczego nieświadomych pacjentów? Czy pacjenci potrafiliby odróżnić dobrych od złych lekarzy? Czy na wolnym rynku lekarze nie zyskaliby zbyt dużej przewagi nad pacjentami?

\subsection{Asymetria informacji w relacji lekarz-pacjent}

Kwestia ta wydaje się szczególnie istotna ze względu na problem asymetrii informacji w relacji między lekarzem a pacjentem. O asymetrii informacji możemy mówić, gdy jedna ze stron transakcji dysponuje dużo większą wiedzą na temat wymienianego produktu/usługi niż strona druga i nie istnieje żadna prosta metoda pomagająca drugiej stronie zdobyć tę wiedzę. W efekcie sprzedawca jest w stanie sprzedać produkt o zaniżonej jakości/zawyżonej cenie, a klient nawet po dokonaniu transakcji może nie być świadomy, że został oszukany. Podręcznikowym przykładem są mechanicy samochodowi. Ponieważ przeciętny klient nie zna się na samochodach, a dodatkowo nie ma technicznej możliwości, by samodzielnie zdiagnozować, co się popsuło, mechanik może go okłamać, wyolbrzymiając skalę problemu i zawyżając koszty naprawy. Dodatkowo, jeśli podczas naprawy popeł- 
ni jakieś błędy, będzie w stanie ukryć je przed klientem. Może się wydawać, że mechanik samochodowy praktycznie zawsze będzie mógł zawyżać cenę/obniżać jakość swych usług 28 .

Podobne problemy pojawiać będą się w relacji lekarz-pacjent. Pacjent dysponuje znacznie mniejszą wiedzą medyczną niż lekarz, przez co trudno będzie mu kontrolować jego działania. Lekarz będzie mógł zawyżać ceny leczenia, zalecać terapie, które nie są korzystne dla pacjenta (ale są korzystne ze względów finansowych dla lekarza lub współpracujących z nim korporacji farmaceutycznych) i ukrywać swoje zaniedbania oraz błędy, unikając konsekwencji (zarówno prawnych, jak i ekonomicznych). Możliwość ukrywania błędów i zaniedbań jest tym groźniejsza, że nie tylko pozwoli na celowe oszustwa, ale osłabi również lęk lekarza przed popełnieniem błędu, obniżając jakość usług. Pojawiają się tu także istotne różnice $\mathrm{w}$ porównaniu do relacji mechanik-klient, które czynią problem asymetrii informacji szczególnie niebezpiecznym w przypadku opieki medycznej: (a) zdrowie jest cenniejsze niż samochód, (b) wycofanie się z leczenia u lekarza, którego podejrzewamy o niekompetencję, może wiązać się z dużymi kosztami (na przykład opóźnienia w terapii), (c) sytuacja medyczna pacjenta jest przeważnie bardziej skomplikowana niż sytuacja zepsutego samochodu. Czy wolny rynek będzie potrafił poradzić sobie z problemem asymetrii informacji w relacji lekarzpacjent?

Podstawowym mechanizmem zapewniającym wysoką jakość usług medycznych w ładzie wolnorynkowym byłby mechanizm konkurencji między producentami, którzy musieliby walczyć o względy konsumentów, obniżając ceny i zwiększając jakość. Problem asymetrii informacji może jednak zakłócić działanie tego mechanizmu. Najpierw powiemy więc o paru specyficznych mechanizmach, za pomocą których problem ten byłby rozwiązany, a potem wrócimy do kwestii rynku jako gwaranta jakości usług medycznych.

\subsection{Możliwość pozwania lekarza za błąd medyczny}

Pierwszym zjawiskiem, które ograniczałoby zakres problemu asymetrii informacji, byłaby możliwość pozwania lekarza za błąd lekarski (Epstein, 1986; Goodman,

28 Sprawa nie jest jednak tak prosta: (1) mechanik nie może przesadzić z zawyżaniem ceny, gdyż klient zwróci się do innego mechanika z prośbą o nową wycenę, (2) jeśli mechanik przesadzi z ceną i klient znajdzie innego mechanika, który wykona usługę taniej, klient może zniechęcić innych klientów do korzystania z usług nieuczciwego mechanika, (3) jeśli w biznesie mechaników samochodowych można byłoby rzeczywiście zanotować ponadprzeciętne zyski, „,goląc frajerów”, można przypuszczać, że powstawałoby coraz więcej warsztatów samochodowych i musiałyby one, by utrzymać się na rynku, obniżyć ceny, (4) im bardziej mechanicy będą zawyżać ceny napraw, tym więcej klientów będzie próbować naprawiać samochody samodzielnie (co w przypadku nieskomplikowanych napraw jest możliwe), zmuszając mechaników, by — jeśli chcą zachować klientów — przynajmniej na niektórych obszarach nie oszukiwali, (5) na rynku będą pojawiać się mechanicy, którzy z jakichś względów (dlatego że wchodzą na rynek, dlatego że chcą być uczciwi) nie będą oszukiwać i którzy zmuszać będą nieuczciwych mechaników do obniżania cen.

Ekonomia - Wroclaw Economic Review 26/1, 2020

(C) for this edition by CNS 
2007; Goodman, 2012). Pojęcie błędu lekarskiego rozumiemy tu w najszerszym znaczeniu obejmującym także różnego rodzaju zaniedbania. Sprzedając usługę medyczną, lekarz podpisywałby z pacjentem umowę, w której zobowiązywałby się wykonać określoną procedurę z zachowaniem należnej staranności i zgodnie z obowiązującą wiedzą medyczną. Gdyby pacjent obawiał się, że lekarz nie dopełnił zasad staranności lekarskiej (co na przykład zaowocowało niewłaściwą diagnozą lub błędem podczas operacji) lub wprowadził pacjenta w błąd, pacjent mógłby pozwać lekarza o złamanie zasad umowy i pociągnąc go do odpowiedzialności - finansowej czy karnej. Powodem pozwu byłoby nie tylko sprzedanie produktu niezgodnego z opisem (lekarz obiecywał dokładnie zbadać pacjenta, a zrobił to pobieżnie, lekarz obiecywał działać w zgodzie z wiedzą lekarską, a pominął istotne wskazania naukowe $\mathrm{w}$ danej kwestii ${ }^{29}$ ), ale także narażenie go na utratę zdrowia, a nawet życia ${ }^{30}$.

Teoretycznie lekarze mogliby chronić się przed pozwami, zastrzegając w umowie, że nie ponoszą odpowiedzialności za potencjalne błędy. Tacy lekarze zostaliby jednakże szybko wyparci z rynku przez lekarzy, którzy dobrowolnie przyjmują na siebie odpowiedzialność za ewentualnie popełnione błędy. Jeśli jakiś lekarz ma zamiar zarabiać, wykonując sumiennie swoją pracę, a nie oszukując pacjenta, opłacałoby mu się wziąć na siebie taką odpowiedzialność — byłoby to bowiem dla pacjentów czytelnym sygnałem kompetencji i uczciwości lekarza. U lekarza takiego warto byłoby się leczyć nie dlatego, że rzeczywiście pojawiłaby się potrzeba pozywania go (pozwy miałyby miejsce niezwykle rzadko), ale dlatego, że samo ryzyko bycia pozwanym powodowałoby, że lekarz robiłby wszystko, by nie popełnić błędu. Błędy nadal by się zdarzały i wtedy lekarze musieliby płacić odszkodowanie, ale byłyby to błędy wynikające $\mathrm{z}$ tego, że jesteśmy niedoskonali, a nie z tego, że nawet nie staramy się być dobrzy ${ }^{31}$. By posiadać zasoby na opłacenie kosztownego odszkodowania, lekarze ubezpieczaliby się od popełnienia błędów medycznych.

${ }^{29}$ Za sprzedaż produktu niezgodnego z opisem można uznać także różne formy medycznej szarlatanerii — na przykład sprzedaż suplementu diety jako „leku na raka”. W konsekwencji producenci oferujący tego typu usługi musieliby bardzo wyraźnie ostrzegać swoich klientów, że sprzedawane przez nich usługi nie mają — wedle aktualnej wiedzy medycznej — żadnych dowiedzionych skutków terapeutycznych.

${ }^{30}$ Widać tu interesującą różnicę w porównaniu z relacją kierowca-mechanik. Ponieważ popełnienie błędu lekarskiego może mieć wielkie konsekwencje zdrowotne dla pacjenta, a więc w efekcie - wielkie konsekwencje finansowe (a nawet karne) dla lekarza, lekarze byliby o wiele mniej skłonni do oszustw i popełniania błędów oraz zaniedbań.

31 Sprawa jest, jak zawsze, nieco bardziej skomplikowana. Dążenie do eliminacji błędu za wszelką cenę nie jest korzystne dla pacjentów. Gdyby lekarze chcieli upewnić się, że każda ich decyzja jest w 100\% uzasadniona, zlecaliby na przykład olbrzymią liczbę dodatkowych badań, obciążając pacjenta kolejnymi kosztami. W dalszej perspektywie czasowej wypracowano by rynkowe equilibrium między chęcią uniknięcia błędu a niechęcią do zbytniego obciążania pacjenta kosztami konieczności uniknięcia błędu. 


\subsection{Prywatne licencje do wykonywania zawodu lekarza}

Możliwość pozwania lekarza za błąd byłaby znaczącym mechanizmem dyscyplinującym, ale jej działanie mogłoby być ograniczone do bardziej poważnych przypadków zaniedbań. Wydajny system prawny eliminowałby lekarzy niekompetentnych, oszustów i szarlatanów, ale nie pozwalałby różnicować między lekarzami średnimi, dobrymi i bardzo dobrymi. Istnieje jednakże proste rozwiązanie tej kwestii: lekarze mogą nie tylko reklamować się jako kompetentni i uczciwi, ale mogą również próbować udowodnić klientom swoje kompetencje i uczciwość. Mogliby to osiągnąć, poddając się ocenie niezależnych instytucji licencjonujących wykonywanie zawodu lekarza bądź oceniających poszczególne obszary kompetencji lekarzy (Svorny, 1992; 2000; 2008). Takie niezależne instytucje organizowałyby kursy oraz egzaminy, których zdanie dowodziłoby kompetencji na danym obszarze. Egzaminy miałyby bardzo różny charakter: od dowodzących ogólnych kompetencji medycznych (przypominających obecny państwowy egzamin lekarski), przez bardziej kierunkowe (przypominające dzisiejsze egzaminy specjalizacyjne), po dotyczące bardzo konkretnych kompetencji (na przykład określonych zabiegów czy badań). W kontekście zabiegów, których skuteczne wykonywanie wymagałoby nie tylko wiedzy czy umiejętności, ale i doświadczenia, organizowane byłyby staże, na których doświadczeni operatorzy wdrażaliby do samodzielnego wykonywania danej procedury. Tego typu kursy i egzaminy organizowane byłyby przez zarówno szkoły medyczne, prywatne firmy certyfikujące, jak i instytucje innego typu (organizacje zrzeszające lekarzy danej dziedziny, na przykład chirurgów czy radiologów). Miałyby one prawdopodobnie charakter niejednorazowy — lekarze, którzy chcieliby zachować swą licencję (wydaną przez daną instytucję), musieliby podchodzić do nich kilkukrotnie w trakcie swojej kariery. Jest to istotne z tego względu, że medycyna rozwija się z roku na rok i lekarze powinni być na bieżąco z nowymi technologiami, technikami operacyjnymi (w przypadku chirurgów) i najnowszymi zaleceniami dotyczącymi leczenia określonych chorób.

Choć lekarze nie musieliby zdawać tych egzaminów, klienci wybieraliby lekarzy, którzy mieliby za sobą takie egzaminy, ich pomyślne zaliczenie byłoby bowiem czytelnym sygnałem kompetencji. Chęć zasygnalizowania pacjentom własnych kwalifikacji nie byłaby jedynym powodem, dla którego lekarze musieliby zdobywać prywatne licencje. Jak wspominaliśmy, lekarze, obawiając się pozwu ze strony pacjentów, wykupowaliby ubezpieczenia od popełnienia błędu lekarskiego. Jednak firmy ubezpieczeniowe nie chciałyby ubezpieczać lekarzy, po których można się spodziewać dużego prawdopodobieństwa popełnienia błędu, lub proponowałyby im bardzo wysokie stawki ubezpieczenia. W jaki sposób firmy ubezpieczeniowe oceniałyby, czy ich potencjalny klient jest obarczony ryzykiem ubezpieczeniowym? Po pierwsze, śledziłyby jego dotychczasową profesjonalną historię $^{32}$, po drugie, żądałyby, by wylegitymował się dowodami kompetencji,

${ }^{32}$ Historia błędów medycznych popełnianych w przeszłości koreluje $\mathrm{z}$ aktualną jakością świadczonych usług (Weycker, Jensen, 2000).

Ekonomia - Wroclaw Economic Review 26/1, 2020

(C) for this edition by CNS 
szczególnie gdyby dopiero zaczynał działalność lub poszerzał obszar zawodowej praktyki. Takim dowodem byłaby, w pierwszym rzędzie, posiadana licencja do wykonywania zawodu (czy określonego zestawu praktyk) wydana przez uznaną prywatną instytucję. Licencji wymagaliby nie tylko klienci i ubezpieczyciele, ale również pracodawcy lekarzy. Lekarz chcący zatrudnić się w szpitalu czy sieci przychodni, które wyrobiły sobie dobrą reputację, musiałby dowieść pracodawcy swoich kompetencji, co mógłby zrobić, między innymi przedstawiając prywatną licencję. I wreszcie ubezpieczyciele wymagaliby od pacjentów, by ci leczyli się tylko u sprawdzonych lekarzy. Ubezpieczycielowi zależałoby, by pacjent został jak najszybciej wyleczony i by potrzeba ponoszenia dalszych kosztów ustała. To, że pacjent leczy się u niekompetentnego lekarza, może być bardzo niekorzystne dla ubezpieczyciela, gdyż może doprowadzić do eskalacji kosztów medycznych $^{33}$. Niekompetentny lekarz błahą chorobę zmieni w poważną, chorobę dającą się leczyć zachowawczo - w wymagającą operacji itp. Wydaje się więc, że praktycznie wszystkie strony zainteresowane byłyby tym, by lekarze mieli oferowane na wolnym rynku licencje poświadczające ich kompetencje:

(1) konsumenci wybieraliby lekarzy z licencjami, szukając pewności, że są oni kompetentni;

(2) lekarze chcieliby zdobyć licencje, by przekonać do siebie pacjentów i móc się ubezpieczyć;

(3) pracodawcy wymagaliby licencji od pracowników, by nie zatrudnić niekompetentnych lekarzy i nie narazić swej firmy na utratę reputacji;

(4) ubezpieczyciele wymagaliby licencji od lekarzy chcących wykupić u nich ubezpieczenie;

(5) ubezpieczyciele wymagaliby od pacjentów, by ci leczyli się u licencjonowanych lekarzy.

Wszystko to pozwala wierzyć, że prywatne licencje byłyby szeroko rozpowszechnione w systemie CPOM. Na tej samej zasadzie działałyby licencje w przypadku pozostałych zawodów medycznych: pielęgniarek, ratowników, fizjoterapeutów i techników medycznych. I w tych zawodach formalne wykształcenie i posiadanie licencji nie byłoby wymagane przez państwo, ale oddolnie wytworzyłyby się mechanizmy zmuszające osoby chcące praktykować te zawody do zdobycia odpowiedniego wykształcenia i licencji zawodowych.

Jak dotąd próbowaliśmy pokazać, że na wolnym rynku oddolnie odtworzone zostałyby obostrzenia podobne do tych, które aktualnie obowiązują lekarzy państwowych. W tym momencie możemy jednakże „przejść do ofensywy” i wskazać, dlaczego system prywatnych licencji byłby lepszą metodą kontroli jakości niż system państwowy. Wolny rynek wytworzyłby zróżnicowany, elastyczny, dopasowany do konkretnego obszaru aktywności medycznej i jego skomplikowania system

$33 \mathrm{Z}$ tego względu korzystanie z niektórych typów tak zwanych alternatywnych metod leczenia nie tylko nie byłoby refundowane, ale prawdopodobnie również (pod groźbą utraty ubezpieczenia) zabronione. 
licencji, który nie byłby ani przesadnie luźny (tak, by nie dopuszczał do wykonywania procedur medycznych osób do tego niepowołanych), ani przesadnie surowy (tak, by nie zmniejszał podaży usług medycznych, blokując prawo do wykonywania procedur osobom, które mogą je z powodzeniem wykonywać). System ten nie byłby narzucony odgórnie przez monopolistycznego regulatora, ale zostałby stworzony metodą prób i błędów oraz ciągłych udoskonaleń przez wiele podmiotów (z kluczową rolą firm ubezpieczeniowych), które wspólnym wysiłkiem ustaliłyby, posługując się wymierną jednostką miary, jaką są pieniądze (ma to znaczenie fundamentalne), odpowiedni poziom wiedzy i doświadczenia, którym należy dysponować, by móc wykonywać daną procedurę. Taki oddolnie wytworzony system licencji mógłby o wiele lepiej dostosowywać się do zmieniającego się środowiska technologicznego, zmieniających się zaleceń medycznych, zmian w podaży usług i zasobności przeciętnych pacjentów. Wobec braku systemu cen i zachęt ekonomicznych do efektywnego działania oraz niemożności wykorzystania rozproszonej, lokalnej wiedzy system licencji i regulacji tworzony przez państwo będzie zawsze nieefektywny, co skutkować będzie ograniczeniem podaży oraz dopuszczaniem do wykonywania zawodu osób do tego niepożądanych.

\subsection{Inne metody sygnalizowania i gwarantowania jakości}

Wobec tego, że konsumenci mogliby mieć problem z odróżnianiem dobrych i złych producentów, w interesie producentów leżałoby, by przekonać pacjentów (nie słowami, ale z zastosowaniem mechanizmu sygnalizowania lub umów), że to właśnie oni oferują usługi najwyższej jakości (Leeson, 2008). To tylko kwestia czasu, gdy producenci tego typu usług wymyślą i wdrożą metody gwarantujące klientom jakość, przejmując tym samym większą część rynku (Shmanske, 1996). A wtedy pozostałym graczom nie pozostanie nic innego, jak naśladować te metody. Jeżeli na jakimś rynku pojawia się problem asymetrii informacji lub jakiejś innej formy zawodności, konkurencję rynkową wygra w dalszej perspektywie czasowej ten, kto będzie umiał znaleźć na nią odpowiedź - warunki efektywnego działania rynku również są czymś, co może być produkowane na rynku. Producenci usług medycznych próbowaliby więc sygnalizować swoje kompetencje i uczciwość nie tylko poprzez zdobywanie licencji, ale i na inne sposoby. Wśród takich metod można wymienić publikacje dokładnych danych statystycznych na temat działań danej placówki medycznej, na przykład statystyk dotyczących wykonanych zabiegów. Pacjenci porównywaliby statystyki, oceniając liczbę pojawiających się niepożądanych komplikacji operacyjnych, czas pobytu w szpitalu itp. Producenci nie byliby zobligowani, by publikować takie dane, ale byłoby to w najlepszym interesie przodujących producentów. Prywatne podmioty świadczące usługi medyczne mogłyby również poddawać się audytom prywatnych firm oceniających jakość, by przekonać klientów o swej uczciwości. Inną praktyką mogłoby być na przykład filmowanie wszystkich zabiegów przeprowadzanych w szpitalu i udo- 
stępnianie ich - w razie potrzeby - firmom ubezpieczeniowym, jednostkom audytującym czy pacjentom, którzy byliby przekonani, że lekarz popełnił błąd, co wydatnie ułatwiałoby dochodzenie praw przed sądem. Możemy spekulować, że najlepsi producenci znaleźliby odpowiednie metody, by odróżnić się od gorszych producentów — robiliby to, ostatecznie, dążąc do maksymalizacji swojego zysku.

\subsection{Wolny rynek jako gwarant jakości usług medycznych}

Jak widać, istnieją skuteczne metody, dzięki którym rynek usług medycznych może radzić sobie z problemem asymetrii informacji. Ponieważ problem ten nie byłby w stanie zakłócić funkcjonowania rynku, możemy uznać, że najważniejszy mechanizm zapewniania jakości na wolnym rynku — konkurencja między podmiotami świadczącymi usługi medyczne - działałby bez zakłóceń. Zgoła odmiennie wygląda sytuacja w systemie państwowym, w którym zlikwidowana została oparta na zasadach rynkowych konkurencja między producentami zdrowia. Wydaje się paradoksem, że to zwolennicy CPOM muszą tłumaczyć, w jaki sposób ich system zapewni jakość usług medycznych, ostatecznie bowiem to państwo wyeliminowało najważniejsze czynniki gwarantujące jakość: konkurencję między podmiotami i system cen.

\section{Podsumowanie}

1. W systemie całkowicie prywatnej opieki medycznej usługi medyczne opłacano by na dwa sposoby:

(a) za pomocą opłat bezpośrednich lub abonamentów płacono by za wizyty u lekarza, podstawowe badania oraz relatywnie tanie zabiegi i operacje;

(b) bardziej poważne operacje, leczenie chorób przewlekłych i długotrwałą rehabilitację finansowano by za pomocą ubezpieczeń medycznych.

2. By zabezpieczyć się przed problemem już istniejących chorób, konsumenci kupowaliby ubezpieczenie z gwarancją odnawialności lub wykupowaliby oprócz podstawowego ubezpieczenia medycznego - ubezpieczenie od zmiany statusu zdrowotnego.

3. Można spekulować, że koszty usług medycznych w ładzie wolnorynkowym byłyby o wiele niższe niż w ładzie państwowym:

(a) ponieważ system oparty byłby na konkurencji, istniałyby silne zachęty ekonomiczne do zwiększania jakości i obniżania ceny, opieka medyczna produkowana byłaby więc o wiele bardziej efektywnie;

(b) ponieważ społeczeństwo byłoby bardziej zamożne, relatywne koszty opieki medycznej zmalałyby, a dodatkowo jednostki decydowałyby o większej części swych zarobków, przez co mogłyby przeznaczyć odpowiednio większą ich część na opiekę medyczną. 
4. Ze względu na internalizację kosztów leczenia (zarówno w przypadku opłat bezpośrednich, składek ubezpieczeniowych, jak i możliwości uzyskania pomocy charytatywnej), ludzie mieliby istotną zachętę ekonomiczną, by żyć w zdrowy sposób. Nie obniżałoby to cen usług medycznych, ale zmniejszałoby zapotrzebowanie na nie, obniżając tym samym ponoszone przez jednostkę koszty opieki medycznej.

5. Punkty 3 i 4 pozwalają wierzyć, że przeciętna osoba byłaby w stanie kupić usługi medyczne przynajmniej na poziomie, na jakim gwarantuje je aktualnie państwo.

6. Osoby, które nie miałyby pieniędzy na leczenie, mogłyby liczyć na pomoc ze strony rodziny, bliskich, lokalnych wspólnot lub instytucji charytatywnych. Ponieważ społeczeństwo libertariańskie stwarzałoby odpowiednie zachęty ekonomiczne do pracy i zdrowego życia, liczba osób chorych i nieposiadających środków wystarczających do opłacenia opieki medycznej byłaby niewielka.

7. Wysoka jakość usług medycznych zapewniana byłaby przez: (1) konkurencję między producentami, (2) możliwość pozwania przez pacjentów lekarzy i placówek opieki medycznej, (3) oddolnie wytworzony system prywatnych licencji, których wymagaliby zarówno klienci, pracodawcy, jak i ubezpieczyciele.

\section{Bibliografia}

Arrow, K. (1963). Uncertainty and the Welfare Economics of Medical Care. American Economic Review, 53, 5.

Bundorf, K., Pauly, M. (2006). Is Health Insurance Affordable for the Uninsured? Journal of Health Economics, 25, 4.

Cannon, M., Tanner, M. (2007). Healthy Competition. What's Holding Back Health Care and How to Free It. Washington (DC): Cato Institute..

Cawley, J., Meyerhoefer, C. (2012). The medical care costs of obesity: An instrumental variables approach. Journal of Health Economics, 31, 1.

Cochrane, J. (1995). Time-consistent health insurance. The Journal of Political Economy, 103, 3.

Cochrane, J. (2009). Health-Status Insurance. How markets can provide health security. Policy Analysis, 633.

Cochrane, J. (2015). After ACA — freeing the market for health care. W A. Malani, M. Schill (red.), The Future of Healthcare Reform in the United States. Chicago (IL).

Downs, A. (1964). Inside bureaucracy. Boston (MA): Rand Corporation.

Edwards, J. (2007). The Costs of Public Income Redistribution and Private Charity. Journal of Libertarian Studies, 21, 2.

Eichner, M., McClellan, M., Wise, D. (1998). Insurance or self-insurance? Variation, persistence, and individual health accounts. W D. Wise (red.). Inquiries in the Economics of Aging. Chicago (IL).

Epstein, R. (1986). Medical Malpractice, Imperfect Information, and the Contractual Foundation for Medical Services. Law and Contemporary Problems, 49, 2.

Friedman, D. (2014). Machinery of Freedom. A Guide to a Radical Capitalism. New York: Open Court.

Goodman, J. (2007). Malpractice Reform: Ten Principles of a Rational Tort System. W J. Goodman (red.) Handbook on State Healthcare Reform. Dallas (TX): National Center for Policy Analysis.

Goodman, J. (2012). Priceless: Curing our Healthcare Crisis. Oakland (CA): Independent Institute.

Ekonomia - Wroclaw Economic Review 26/1, 2020

(C) for this edition by CNS 
Goodman, J., Musgrave, G. (1992). Patient Power: Solving America's Health Care Crisis. Washington (DC): Cato Institute.

Handel, B., Hendel, I., Whinston, M. (2017). The welfare effects of long-term health insurance contracts. NBER Working Paper, 23624.

Hasnas, J. (2003). Reflection on the minimal state. Politics, Philosophy and Economics, 2, 1.

Herring, B., Pauly, M. (2006). Incentive-Compatible Guaranteed Renewable Health Insurance Premiums. Journal of Health Economics, 25.

Herzlinger, R. (red.) (2004). Consumer-Driven Health Care: Implications for Providers, Payers, and Policy-Makers. San Francisco (CA): Jossey-Bass.

Holcombe, R. (2004). Government - Unnecessary but Inevitable. The Independent Review, 8, 3.

Huemer, M. (2019). Problem władzy politycznej. O przymusie i postuszeństwie. przeł. J. Lewiński, P. Świercz. Wrocław: Instytut Ludwiga von Misesa.

Iuga, A.O., McGuire, M.J. (2014). Adherence and health care costs. Risk Management and Healthcare Policy, 7.

Juarez, D., Goo, R., Tokumaru, S., Sentell, T. (2013). Association Between Sustained Glycated Hemoglobin Control and Healthcare Costs. The American Journal of Pharmacy Benefits, 5, 2.

Kini, V., Ho, P.M. (2018). Interventions to Improve Medication Adherence: A Review. JAMA, 18, 320.

Kunreuther, H., Pauly, M. (2005). Insurance Decision-Making and Market Behavior. Foundation and Trends in Microeconomics, 1, 2.

Lalonde, M. (1974). A New Perspective on the Health of Canadians. Ottawa.

Leeson, P. (2008). Social Distance and Self-Enforcing Exchange. The Journal of Legal Studies, 37, 1.

Massaro, T.A., Wong, Y.N. (1995). Positive Experience with Medical savings Accounts in Singapore. Health Affairs, 14, 2.

Nozick, R. (2010). Anarchia, państwo i utopia. przeł. P. Maciejko, M. Szczubiałka. Warszawa: Wydawnictwo Aletheia.

Osterfeld, D. (1986). Freedom, Society \& the State. An Investigation into the Possibility of Society without Government. San Francisco (CA): University Press of America.

Pauly, M. (2019). Giving Competition in Medical Care and Health Insurance a Chance. Arlington (VA): Mercatus Center at George Mason University.

Pauly, M. (2000). Optimal health insurance. The Geneva Papers on Risk and Insurance, 25, 1.

Pauly, M., Herring, B. (1999). Risk Pooling in Health Insurance. Washington (DC): AEI Press.

Pauly, M., Kunreuther, M., Hirth, R. (1995). Guaranteed renewability in insurance. Journal of Risk and Uncertainty, 10.

Rothbard, M. (1998). The Ethics of Liberty. New York: NYU Press.

Rothbard, M. (2006). For a New Liberty. The Libertarian Manifesto. Auburn (AL): Ludwig von Mises Institute.

Schansberg, E. (2011). Envisioning a Free Market in Health Care. Cato Journal, 31, 1.

Schansberg, E. (2014). The Economics of Health Care and Health Insurance. The Independent Review, $18,3$.

Shmanske, S. (1996). Information Asymmetries in Health Services The Market Can Cope. The Independent Review, 1, 2.

Stevens, R. (1989). In Sickness and Wealth: American Hospitals in the Twentieth Century. New York: JHUP.

Stiglitz, J. (2012). Ekonomia sektora publicznego. przeł. R. Rapacki et al. Warszawa: PWN.

Svorny, S. (1992). Should We Reconsider Licensing Physicians? Contemporary Policy Issues, 10.

Svorny, S. (2000). The changing role of licensure in promoting incentives for quality in health care.

W R. Feldman (red.), American Health Care: Government, Market Processes, and the Public Interest. Oakland (CAL).

Ekonomia - Wroclaw Economic Review 26/1, 2020

(C) for this edition by CNS 
Svorny, S. (2008). Medical Licensing. An Obstacle to Affordable, Quality Care. Policy Analysis, 621. Cato Institute.

Svorny, S. (2017). Liberating Telemedicine: Options to Eliminate the State-Licensing Roadblock. Policy Analysis, 826. Cato Institute.

Warren, G.W., Cartmell, K.B., Garrett-Mayer, E., Salloum, R.G., Cummings, K.M. (2019). Attributable Failure of First-line Cancer Treatment and Incremental Costs Associated With Smoking by Patients With Cancer. JAMA Network Open, 5, 2(4).

Weycker, D.A., Jensen, G.A. (2000). Medical malpractice among physicians: Who will be sued and who will pay? Health Care Management Science, 3, 269.

Wójtowicz, S. (2016). Czym jest minarchizm. Societas et Ius, 5.

Wójtowicz, S. (2017). Anarchokapitalizm, czyli czy możemy obyć się bez państwa? Nauka, 4. 